\title{
Disciplining the Professional Judge
}

\author{
Sambhav N. Sankar $\dagger$
}

Recent controversies involving the California Commission on Judicial Performance (CJP) lead the author to investigate the structure and function of judicial conduct organizations. The author suggests that we discipline judges to vindicate three values: democratic public accountability, fidelity to the rule of law, and adherence to public norms of professional conduct. Against each of these goals stand different facets of the norm of judicial independence. The author argues that traditional mechanisms of judicial discipline typically serve one goal and have structural limits to avoid excessive encroachments upon judicial independence. He then compares the CJP with the federal judicial councils, and indicates that structural differences in the two organizations are at the root of the praise and criticism they each receive. The Comment concludes with suggestions to improve the overall effectiveness of the CJP.

\section{INTRODUCTION}

Presiding Justice J. Anthony Kline of the California Court of Appeal knew he would stir legal controversy with his dissent in Morrow v. Hood Communications, Inc. ${ }^{1}$ The parties in Morrow sought the First Appellate District's reversal of the lower court decision in accordance with the California Supreme Court's 1992 opinion in Neary v. Regents of the University of California. ${ }^{2}$ Neary endorsed the practice of stipulated reversal, in which opposing litigants settle a case after a trial court ruling in favor of one party. The victorious party agrees to have the ruling reversed by an

Copyright $\odot 2000$ California Law Review, Inc. California Law Review, Incorporated (CLR) is a California nonprofit corporation. CLR and the authors are solely responsible for the content of their publications.

† Law Clerk to the Honorable William A. Fletcher, United States Court of Appeal for the Ninth Circuit; J.D., School of Law, University of California, Berkeley (Boalt Hall), 2000; M.S., Stanford University, 1994; B.S., Cornell University, 1992. My thanks to the tireless Law Review nembers whose advice shaped this Comment, including Kate Barry, Alistair Newbern, Matt Sarboraria, and iny dear friend Neil Siegel. Thanks also to Professors Jan Vetter and Stephen Barnett for their advice and encouragement, and to Justice J. Anthony Kline for his helpful comments. My deepest gratitude, however, goes to Professor Robert Post, whose artesian intellect will always be an inspiration to me.

1. 69 Cal. Rptr. 2 d 489 (Cal. Ct. App. 1997).

2. 834 P.2d 119 (Cal. 1992). 
appellate court in return for a payment from the vanquished party. ${ }^{3}$ Neary had been the target of much criticism, ${ }^{4}$ and in Morrow, Kline made his own position clear. Acknowledging that Neary constituted controlling precedent, Kline stated his unwillingness to apply its rule to the facts of Morrow. In his words, "[t]here are rare instances in which a judge of an inferior court can properly refuse to acquiesce in the precedent established by a court of superior jurisdiction. This is, for me, such an instance." Although his colleagues on the majority side, Judges Ruvolo and Lambden, "respectfully" stated their agreement with Kline's fundamental stance, ${ }^{6}$ they chose not to join his crusade.

Kline's dissent in Morrow was intended to spur the California Supreme Court to reconsider the practice of stipulated reversal. ${ }^{7}$ In fact, Kline did touch off a firestorm, but not on the issue he had hoped. Although the California Supreme Court chose not to review Morrow, ${ }^{8}$ another body did act on Kline's words, in a manner he could not have foreseen. On July 6, 1998, the California Commission on Judicial Performance (CJP) levied formal charges of "willful misconduct in office, conduct prejudicial to the administration of justice that brings the judicial office

3. The victor thus avoids the difficulty and uncertainty of further appeals, and the vanquished avoids the future effect of an adverse judgment. The California Supreme Court could not have been more clear in its endorsement of this praetice: "[A]bsent a showing of extraordinary circumstances," it stated, "the parties should be entitled to a stipulated reversal." Id. at 121 (emphasis added). The Court justified this holding by declaring that the primary purpose of the judiciary is "to afford a forum for the settlement of litigable matters between disputing parties." Id. at 124 (citation omitted).

4. Neary's first critic was California Supreme Court Justice Joyce Kennard. See id. at 127 (Kennard, J., dissenting). She was soon joincd by academic critics, see, e.g., Stephen R. Barnett, Making Decisions Disappear: Depublication and Stipulated Reversal in the California Supreme Court, 26 LOY. L.A. L. REv. 1033 (1993), who attacked the decision for essentially one reason: Neary allowed well-heeled litigants to "buy back" unfavorable judgments to the detriment of the rule of law. See id. at 1033; see also United States Bancorp Mortgage Co. v. Bonner Mall Partnership, 513 U.S. 18, 26-27 (1994) (stating that parties are not generally entitled to vacatur from federal courts).

5. Morrow, $69 \mathrm{Cal}$. Rptr. 2d at 490-91. Justice Kline cited two law review articles discussing when such "rare instances" exist": Evan H. Caminker, Why Must Inferior Courts Obey Superior Court Precedents?, 46 STAN. L. REv. 817 (1994), and Paul L. Colby, Perspective on the Authoritativentess of Supreme Court Decisions: Two Views on the Legitimacy of Nonacquiescence in Judicial Opinions, 61 TuL. L. REv. 1041 (1987).

6. Morrow, 69 Cal. Rptr. $2 \mathrm{~d}$ at 490.

7. Kline noted three reasons why they should do so. First, citing Bonner Mall, 513 U.S. at 26, he stated that stipulated reversals were "destructive of judicial institutions." Morrow, 69 Cal. Rptr. 2d at 491. Second, the unique posture of stipulated reversal cascs would prevent the Supreme Court from ever revisiting Neary if its rule were mechanically applied. See id. at 493. And third, there was precedent for his point of view-a federal court in Colorado had previously refused to apply the doctrine. See id. (citing Benavides v. Jackson Nat'l Life Ins. Co., 820 F. Supp. 1284, 1285 (D. Colo. 1993)).

8. The Court did, however, conference on whether to do so-an unusual action in the absence of a motion by the parties-and two Justices were of the opinion that the Court should consider Morrow on its own motion. See Supreme Court MrNs. Dec 23, 1997, Off. Reps., Adv. Pamp. No. 4 (1998) p. 19. 
into disrepte, improper action, and dereliction of duty". against Kline for his dissenting remarks. ${ }^{9}$

The CJP's move sparked a wave of indignation, ${ }^{10}$ and support for Kline poured in. Many noted that this was the first time that any such council had acted against an appellate judge for remarks made in a dissenting opinion. ${ }^{11}$ The American Bar Association urged the CJP to withdraw its charges, stating that "this proceeding is a serious and direct challenge to the principle of judicial independence-a tenet central to America's basic precepts of justice." ${ }^{12}$ California judges were especially incensed. One Court of Appeal judge declared, " $\Pi \mathrm{f}$ they're going to burn Justice Kline at the stake, they're going to have a pretty big barbecue, because they're going to burn a lot of judges." ${ }^{13}$ Some observers were suspicious that the CJP's inajority of Republican members was motivated by partisan concerns to attack Kline, a prominent liberal who was appointed by Democratic Governor Jerry Brown. ${ }^{14}$ In a brief filed on Kline's behalf, the California Judges Association expressed concern that any disciplinary action against Kline "would be a severe blow to the judicial function, to the integrity of judicial institutions and to cherished principles of judicial independence." 15

These protests encouraged the California legislature to take action. It passed two bills intended to circumscribe the CJP's authority. One directly prohibited the CJP froin disciplining judges for issuing opinions that are legally incorrect or issuing dissents that do not follow the precedent of a higher court. ${ }^{16}$ The other inandated several modifications to the CJP's procedures designed to affect its decision making in a somewhat less direct inanner. ${ }^{17}$ Although the bills passed the legislature, both were vetoed ${ }^{18}$ by Governor Pete Wilson as "unconstitutional, largely unnecessary, overly broad, and an inappropriate effort to interfere" with the case pending against Kline. ${ }^{19}$

9. Notice of Formal Proceedings at 1 , Inquiry Concerning Justice J. Anthony Kline (Commission on Judicial Performance, June 30, 1998) (No. 151).

10. See George M. Kraw, Judging the Refusenik Judge, ReCORDER, July 15, 1998, at 4.

11. See, e.g., Henry Weinstein, Panel Dismisses Charges Against Appeals Judge, L.A. TimEs, June 21, 1999, at A12.

12. Quoted in Henry Weinstein, Bar Urges Judicial Panel to Drop Charges, L.A. Times, July 17, 1998 , at A17.

13. Ken Garcia, Bashing by Judges Boomerangs, S.F. Chron., July 11, 1998, at A15.

I4. See, e.g., Greg Mitchell, Discipline Case Against Kline Irks Legislators, RECORDER, July 8 , 1998, at 1.

15. Amicus Brief of California Judges Association at 1-2, Inquiry Concerning Justice J. Anthony Kline (Commission on Judicial Performance, April 12, 1999) (No. 151).

16. See A.B. 1110, 1997-1998 Sess. (Cal. 1998) [hereinafter A.B. 1110].

17. See S.B. 1623, 1997-1998 Sess. (Cal. 1998) [hereinafter S.B. 1623].

18. See Order Vetoing S.B. 1623 (Sept. 29, 1998); Order Vetoing A.B. 1110 (Sept. 29, 1998).

19. Order Vetoing A.B. 1110 (Sept. 29, 1998); see also Jurist Protection Rejected, SACRAMENTo BEE, Oct. 2, 1998, at A9. 
In the end, Kline's reprieve came from an unlikely source: the CJP itself. On June 16,1999 , before any formal fact finding, the Commission voted eight to one to drop the charges agaimst him entirely. ${ }^{20}$ The CJP cited an intervening decision by the California Supreme Court, Oberholzer $v$. Commission on Judicial Performance," which held that "[m]ere legal error, without more ... is insufficient to support a finding that a judge has violated the Code of Judicial Ethics and thus should be disciplined. ${ }^{22}$ But observers doubted that Oberholzer was the primary reason for the CJP's change of heart. They pointed out that seven of the Commission's eleven members had been replaced by California's new Governor, Democrat Gray Davis, and that these individuals might have been more politically sympathetic to Kline. ${ }^{23}$ Whatever the reasons for his personal victory, Klime emphasized the broader ineaning of the CJP's decision in his statements to the press, seeing it "not just as a victory for me but for every judge in the state." 24

The CJP's response to Judge Kline's Morrow dissent and the legal commumity's reaction thereto motivate this inquiry into the structure and role of lay commissions on judicial performance..$^{25}$ California was the first state to create an independent body to supervise judicial conduct, ${ }^{26}$ and

20. See Decision and Order of Dismissal, Inquiry Concerning Justice J. Anthoy Kline (Commission on Judicial Performance, Aug. 19, 1999) (No. 151); see also Seth Rosenfeld, Judicial Independence Wins Out, S.F. EXAMINER, Aug. 20, 1999, at A5. Note that this was the first time the CJP published the votes of its members: it was compelled to do so by a lawsuit filed by a California legal newspaper and Boalt Hall Professor Stephen Barnett. See Recorder v. Commission on Judicial Performance, 72 Cal. App. 4th 258 (1999).

21. 975 P.2d 663 (Cal. 1999).

22. Id. at 680 .

23. Kline himself is less sure of the reasons for the dismissal of his case. He notes that several members whose terms did not expire after the election also changed their votes, and speculates that public disapproval of the CJP's actions and support for judicial independence was at least partially the reason for the dismissal. See Interview with J. Anthony Kline, Presiding Justice, in San Francisco, Cal. (April 7, 2000).

24. Rinat Fried, CJP Details its Reasons for Clearing Kline, RECORDER, Aug. 20, 1999, at 1. In completion of this victory, the California legislature recently approved a bill, A.B. 1676, 1999-2000 Sess. (Cal. 1999), that bans stipulated reversals in California, effectively overruling Neary by amending Section 128 of the the California Code of Civil Procedure to state that:

An appellate court shall not reverse or vacate a duly entered judgment upon an agreement or stipulation of the parties unless the court finds both of the following:

(A) There is no reasonable possibility that the interests of nonparties or the public will be adversely affected by the reversal.

(B) The reasons of the parties for requesting reversal outweigh the erosion of the public trust that may result from the nullification of a judgment and the risk that the availability of stipulated reversal will reduce the incentive for pretrial settlement.

25. Other scholarly articles have dealt with the Kline controversy in exploring other issues. See, e.g., Pamela S. Karlan, Two Concepts of Judicial Independence, 72 S. CAL. L. Rev. 535, 548-54 (1999); Rory K. Little, Reading Justice Brennan: Is There a Right to Dissent? 50 Hastings L.J. 683, 692-94 (1999).

26. See Irene A. Testitor \& DWight B. SinKs, Judicial Conduct Organizations 2 (1980). 
every other state has followed its lead. ${ }^{27}$ These bodies vary in their composition and specific mandates, but Kline's case provokes questions applicable to all: what are the proper limits of authority for lay commissions on judicial discipline, and how should they be structured to best accomplish their goals? In this Comment, I hope to begin to investigate these questions.

Part I of this Comment suggests that there are three reasons for imposing "judicial discipline": creating democratic public accountability, enforcing adherence to legal standards, and imposing public norms of professional and judicial behavior. Each of these goals lives in tension with various concerns commonly grouped under the heading of "judicial independence." Part II describes in detail one element of judicial independence: the professional independence of the judiciary. This oft-ignored facet of independence is critical to understanding why judges resist some approaches to judicial control while accepting others. Part III describes several mechanisms for judicial control and their relative abilities to satisfy the goals articulated in Part I. It suggests that each of these mechanisms typically addresses one of the three goals articulated earlier and is structured so that it will not be used to vindicate others.

In Part IV, I describe two judicial conduct organizations (JCOs): the California Commission on Judicial Performance (CJP) and the federal judicial councils. Whereas the federal JCOs are internal, professional control organizations run by judges, the CJP is a bureaucratic institution imposed upon the California judiciary. This difference is at the root of both the praise and criticism each JCO has attracted. Finally, Part V suggests that the CJP lacks limits on its authority that would prevent it from attempting to serve all three of the goals articulated in Part I, even though its structure impairs its ability to do so without unduly infringing upon the independence of the judiciary. Therefore, I propose several reforms to increase its effectiveness as a JCO and to properly protect each facet of judicial independence.

\section{I}

\section{Why We IMPOSE Judicial Discipline}

Before asking how best to control judges, it seems essential to ask why we control judges, and what we risk when we do so without warrant. I contend that we discipline $e^{28}$ judges for three essential reasons. The first is for democratic public accountability-so that the governed may safely

27. See Jefrerey M. Shaman et al., Judicial Conduct and Ethics $\S 14.01$, at 489 (2d ed. 1995).

28. Throughout this Comment, I use the word "discipline" to refer broadly to the various ways in which governments attempt to control the conduct, behavior, and decisions of judges. I do not intend to limit this term to mean puuitive sanction or reprimand. 
relinquish control to those who hold authority. The second is to enforce adherence to the law itself-so that neutral principles rather than a judge's personal preferences motivate her decision in each individual case. The third is to ensure that judges conform to professional standards of behavior and conduct-so that in exercising their authority they do not alienate or lose the respect of those who are subjected to it. But any attempt to address these concerns runs the risk of adversely affecting the process of judging or the judicial profession itself. ${ }^{29}$ Concerns of this type are typically grouped under the heading of "judicial independence."

\section{A. Public Accountability and Legitimacy}

The first reason for imposing judicial discipline is simply that in a democracy, citizens must exercise control over their government. Without this control, the fundamental exchange of power from citizen to the government cannot be legitimate. While this need for control is more commonly understood in the context of political officers, it applies to judges as well. Ever since the belief that the law was a set of truths to be revealed by judges became untenable, the process of judging has become increasingly politicized. As a result, some types of judicial discipline involve essentially political concerns. Attempts to remove sitting judges because of their opposition to the death penalty are only the most prominent examples of decisions by the electorate to remove judges who no longer reflect its own beliefs. ${ }^{31}$

It is to this concept that the conventional fornulation of judicial independence stands in counterpoise. Accountability to the will of the electorate does not come without cost: attempts to attune a judiciary to the public will can threaten the very feature that makes that institution uniquely important in democratic society. The framers of our nation recognized this threat, $^{32}$ and many modern scholars agree. ${ }^{33}$ One of the best-known modern

29. See Mary L. Volcansek, Judicial Impeachment: None Called For Justice 2 (1993) [hereinafter VolCANSEK, Judiclal IMPEACHMENT].

30. See John P. Sahl, Secret Discipline in the Federal Courts-Democratic Values and Judicial Integrity at Stake, 70 NOTRE DAME L. REV. 193, 200-06 (1994) (citing innumerable articles on this topic); Symposium, Judicial Independence and Accountability, 72 S. CAL. L. REv. 311 (1999).

31. The most well-known of these situations are the removal of Chief Justice Rose Bird in California and the more recent removal of Tennessee Supreme Court Justice Penny White. See generally John Blume \& Theodore Eisenberg, Judicial Politics, Death Penalty Appeals, and Case Selection: An Empirical Study, 72 S. CAL. L. Rev. 465, 470-75 (1999) (describing these and other instances where judges have been removed through electoral processes because of their opposition to the death penalty).

32. Alexander Hamilton claimed that "independence of the judges is ... requisite to guard the constitution and the rights of individuals [against legislative encroachments and] from the effects of those ill humours which the arts of designing men, or the influence of particular conjunctures, sometimes disseminate among the people themselves ...." ThE FederaList No. 78, at 397 (Alexander Hamilton) (Garry Wills ed., 1982). Those interested in the historical origins of judicial independence should read Louis $H$. Pollak, The Constitutional and Historical Origins of Judicial 
expositions of this argument suggests that the structural role of judicial review is to protect those who lack the numbers and influence to secure protection through the political process, especially when constitutional rights are involved. ${ }^{34}$ Thus, excessive democratic accountability can threaten what I will call the countermajoritarian independence of a judge.

In the federal government, the countermajoritarian face of the independence norm has all but overwhelmed the concept of democratic accountability. To the Framers, the most viable means of ensuring judicial independence was permanency in office, ${ }^{35}$ which translated into a constitutional grant of life tenure for federal judges. Besides the political nature of the appointinent process itself, inpeachment, discussed infra, is the only real means of providing democratic accountability within the federal judiciary. ${ }^{36}$ State governments, while recognizing the value of independence generally, have been less protective of their judiciaries. Most state judges are subject to various removal provisions in addition to traditional impeachment mechanisms. ${ }^{37}$ Nevertheless, even commentators who advocate further political controls upon judges typically continue to recognize independence as the sine qua non of judging. ${ }^{38}$ It thus seems logical that any judicial discipline system should strive to affect independence as little as possible, and that respect for independence and the rule of law may limit the reach of a disciplinary system to less than might otherwise be desirable.

\section{B. Adherence to Legal Norms}

A second reason for imposing discipline is to enforce adherence to legal norms, so that a judiciary's legal decisions are consistent and accurate. To this end, American government uses control inechamisms that review and correct a judge's decisions where necessary. In contrast with review focused upon the manner in which a legal decision is made, these structures focus upon the basic result of a judicial proceeding and its consistency with prior legislative and judicial action. For example, consider how absurd it would be if a California judge ignored jurisdictional requirements $\mathrm{m}$ order to decide a case in Delaware. This decision would defy both precedent and statutory law, and no matter how impartial or fair, the decision would have to be reversed.

Independence: Testimony of Louis H. Pollak Before the Commission on Separation of Powers and Judicial Independence, October 11, 1996, 12 ST. JOHN's J. LEG. COMMENT. 59 (1996). See also Stephen B. Burbank, The Architecture of Judicial Independence, 72 S. CAL. L. Rev. 315 (1999).

33. See, e.g., MARTIN Shapiro, Courts 20 (1981).

34. See Jesse H. Choper, Judicial Review and the National Political Process (1980).

35. See The Federalist No. 78, supra note 32, at 394.

36. But see Burbank, supra note 32, at 321-22 (discussing other means for controlling the judiciary generally, rather than judges individually).

37. See SHAMAN ET AL., supra note $27, \$ 1.03$, at 7.

38. See, e.g., id. $\$ 1.03$, at 1-3; MODEL CodE of Judrcial Conduct Canon 1A (1990) ("An independent and honorable judiciary is indispensable to justice in our society."). 
As with democratic public accountability, there are risks to overly aggressive review of legal decisionmaking by a judge. And once again, these risks are often lumped under the catch-all heading of judicial independence. Here, however, it is not the countermajoritarian independence of the judiciary that is at issue, but rather its unique place in American governance systems. ${ }^{39} \mathrm{~A}$ legislature that had the power to both make and interpret law would have little incentive to phrase statutes precisely or to carefully consider their future consequences. Thus, tripartite governnent structures require limits on legislative interference with the judicial function. The most critical is that political branches must not attenipt to invade the judging function by directing the rule of decision in a pending legal case or by reopening final judicial determinations ${ }^{40}$ Of course, judge-niade law is effectively overruled by legislation on a regular basis. ${ }^{41}$ However, this is not review of a judge's legal decision, but rather the substitution of political authority for judicial reasoning im future cases. Judicial independence in the arena of adherence to legal norms, which I will refer to as legal independence, is an expectation on the part of the judiciary that it will be left to police its own adherence to legal norms. In our political systent, only a judge can review the legal decision of another judge.

The need for a structurally independent judiciary illuminates the expectation that a judge will respect the legal judgnients of his peers. Since other branches of government cannot review a judge's decision in a case, the integrity of the legal system relies upon each individual judge's adherence to precedent, compliance with orders from superior courts, and respect for the validity of prior judgments. The popularly iniagined independent judge is slavishly deferent to his superiors because the judicial inonopoly on legal decision niaking presupposes his hierarchical behavior. Just as some mstitutions of judicial control focus on aligning a judge with popular will, others ensure that his reasoning accords with that of his peers and superiors. Structures built to enforce the latter may properly be regarded as disciplinary systems, and I will analyze them as such. ${ }^{42}$

39. See Burbank, supra note 32, at 318-35 (arguing that these concerns form the true core of the concept of judicial independence).

40. See, e.g., Plaut v. Spendthrift Farm, Inc., 514 U.S. 211, 224 (1995); United States v. Klein, 90 U.S. (13 Wall.) 128 (1871). I would betray one of my distinguished teachers if I failed to note that the precise holding of Klein is elusive, and that this pedestrian interpretation may in fact be overly simplistic. See Richard H. Fallon, et al., HaRT AND WeChSLER's the Federal CourTs and the Federal System 367-69 (4th ed. 1996); Lawrence G. Sager, Klein's First Principle: A Proposed Solution, 86 GEO. L.J. 2525, 2525 (1998) (opining that even the United States Supreme Court "never seems to be particularly secure about exactly what the principle of Klein is."). It is, however, the proposition for which the ease is commonly cited.

41. See A.B. 1676, supra note 24 , for a fitting example.

42. These structures mclude the principle of stare decisis and the appellate powers of reversal and mandamus. See infra Part III.B. 


\section{Competence and Behavior}

Although correctly applying existing law is a necessary element of proper judicial behavior, it is not sufficient on its own. As described earlier, where judicial decisions fundamentally misrepresent public sentiment and yet are insulated from legislative alteration, enforcing legal norms will not accomplish all that we seek. ${ }^{43}$ When a judiciary stubbornly expresses an undesirable policy preference through matters of discretion not directly related to substantive legal standards (for example, procedural rulings), changing the law may require changing the judge.

But even a judge whose decisions are both legally "correct" and aligned with the popular will can merit discipline. Consider the following courtroom soliloquy by Santa Clara County Superior Court Judge Gerald S. Chargin upon issumg a guilty verdict in the case of a young MexicanAmerican charged with sexual relations with his stepsister:

This is one of the worst crimes that a person can commit. I just get so disgusted that I just figure what is the use? You are just an animal.... I don't know why your parents haven't been able to teach you anything or tram you. Mexican people, after 13 years of age, its perfectly all right to go and act like an animal ....We ought to send you out of the country-send you back to Mexico. .. . Maybe Hitler was right. ${ }^{44}$

This statement is quite intolerable, even though the judge's decision to impose a punitive sentence for incest probably reflects public sentiment and adheres to legal standards. It thus points to a fmal group of reasons to impose discipline: those that revolve around an individual judge's professional competence and behavior. These concerns merit what most readily springs to mind when one thinks of "judicial discipline." As to judges' professional competence, stories abound of drunken, insane, or incompetent judges who threaten not only the interests of individual litigants, but the legitimacy of the entire judiciary. ${ }^{45}$ As to judges' behavior, mistreatment by judges of lawyers, litigants, and jurors is an oft-repeated concern, as is more obviously unethical behavior. These concerns should not be underestimated; they bear heavily upon the public perception of the judiciary and respect for the legal system as a whole. Litigants typically evaluate the

43. One example of such a situation would be where judge-made constitutional law defies legislative alteration. Another would be where judges use proccdural or evidentiary decisions (themselves often of a constitutional nature) to routinely avoid certain substantive legal issues.

44. William Thomas Braithwaite, Who Judges the Judges?: A Study of Procedure for REMOVAL AND RETIREMENT 92 (1971).

45. See, for example, the story of the Judge John Pickering, whose mental disabilities first encouraged New Hampshire politicians to move him from the state to the federal bench. His derangement and alcoholism later culminated in an attempt to cane a lawyer in his court, and because he could not be persuaded to resign, he was finally awarded the distinction of being the first victim of the Impeachment Clause of the Constitution. See Mary L. VolCanseK, Judiclal Misconduct: A Cross-National CoMparison 90-91 (1996) [hereinafter VolCANSEK, Judicial Misconduct]. 
fairness of judicial proceedings at least as much on the basis of their tone and the respect the judge affords the parties as by the actual outcome of the proceeding. ${ }^{46}$

Against the interest in controlling judicial competence and behavior is balanced the most fragile form of judicial independence-the judiciary's professional independence. I use the term "professional" here in its sociological sense; in the next Part of this Comment, I elaborate what it means in that context.

\section{III}

\section{Professional IndePEndence and Bureaucratic Discipline}

In this Part, I suggest that judging is properly regarded as a profession in the sociological sense, and that as a result, bureaucratic approaches to controlling judicial behavior will inevitably run into serious difficulties when they intrude upon areas of professional expertise. Before going further, I should acknowledge that defining the concept of the "professional" is no easy task..$^{47}$ Sociologists typically approach the problem by portraying professionalism as a scale of behavior rather than an exclusive cluster of attributes, ${ }^{48}$ and placing occupations along a spectrum from the nonprofessional to the professional..$^{49}$ For this reason, it is impossible for me to "prove" that judges are professionals. ${ }^{50}$ Yet it seems clear that the occupation of judging has many characteristics of a profession, subject to some important qualifications.

Peter Blau identifies five general traits of professional fields. ${ }^{51}$ First, the decisions of their members are normally governed by universalistic standards-criteria independent of the case under consideration. ${ }^{52}$ These

46. See Robert J. MacCoun et al., Alternative Dispute Resolution in Trial and Appellate Courts, in The HaNdboox of PsYchology and Law 95 (D.K. Kagehiro \& W.S. Laufer eds., 1992); E. Allan Lind et al., In the Eye of the Beholder: Tort Litigants' Evaluations of Their Experiences in the Civil Justice System, 24 LAw. \& Soc. Rev. 953 (1990).

47. See Richard A. Posner, J. Byron McCormick Lecture: Professionalisms, 40 ARIz. L. Rev. 1, 1 (1998).

48. See, e.g., Wilbert E. Moore, The Professions: Rol.es and Rules 5 (1970). Moore includes among his factors whether the professional practices his occupation full-time, has an enduring set of normative and behavioral expectations, possesses specialized training or esoteric knowledge, is oriented towards service, and is autonomous. See id.

49. See, e.g., Paul D. Montagna, Occupations and Society 197 (1977).

50. See MOORE, supra note 48, at 4-5.

51. See Peter M. Blau \& W. Richard Scott, Formal Organizations: A Comparative APPROACH 60 (1962). Virtually every sociologist who studies professions seems to have her own list of attributes, see MONTAGNA, supra note 49 , at 213 n.5 (listing a variety of approaches and citing several key attributes), but Blau's list seems to my untrained eye one of the more carefully supported.

52. See Blau \& ScotT, supra note 51, at 60; MonTagna, supra note 49, at 174; W. Richard Scott, Professionals in Bureaucracies-Areas of Conflict, in Professionalization 268 (Howard M. Vollmer \& Donald L. Mills eds., 1966). 
standards come from specialized knowledge acquired by training, ${ }^{53}$ and professional practice consists of applying it to particular situations. Second, professionals normally have a specific expertise and make no claim to general knowledge. ${ }^{54}$ Third, they maintain neutrality towards clients. ${ }^{55}$ Fourth, status within a profession is normally achieved through merit, and fifth, professional decisions generally avoid serving self-interest im favor of valuing client interests. ${ }^{56}$

Applying Blau's scale to the judiciary is instructive. ${ }^{57}$ Judges are almost always drawn from the ranks of lawyers, a group that is almost unquestionably a profession in the sociological sense. ${ }^{58}$ Further, judges display many of Blau's professional traits-affected neutrality, ${ }^{59}$ disclaimers of general knowledge, ${ }^{60}$ and so on. On the other hand, judges, unlike most other professionals, usually obtain their positions through political appointment or the electoral process, not merit, ${ }^{61}$ and normally do not control advanceinent within their own ranks. Certainly, judges have special knowledge, but it is not exercised in a vacuum. Unlike doctors, whose scientific assessments are generally made without reference to publicly developed standards, judges work with the public will-in the form of legislation-in virtually all of their decisions. The judicial profession involves, strangely enough, the enforcement of the public's self-imposed rules. Therefore, a judge's independent professional judgment is not truly independent, and his specialized knowledge is quite different from that of a physicist or even a lawyer. ${ }^{62}$

53. See Blau \& Scott, supra note 51, at 60; ANthony Giddens, Sociology 296 (2d ed. 1993). But see Posner, supra note 47, at 2 ("The key to classifying an occupation as a profession, it must be emphasized, is not the actual possession of specialized... knowledge [but] the belief that some group has such knowledge .... .) (emphasis added).

54. See BLAU \& SCOTT, supra note 51, at 61-62.

55. See id.

56. See id.

57. Cf. Montagna, supra note 49 , at 197 (placing judges at the apex of a scale of professionals, even more "professional" than doctors).

58. See Posner, supra note 47 , at 2. Posner acknowledges that sociologists consider lawyers members of a profession, but then goes on to chastise the profession for its lack of "professionalism." See id.

59. See MOdel Code of Judicial Conduct Canon 3E (1990) (discussing standards for disqualification); SHAMAN ET AL., supra note $27, \$ 4.01$, at 95.

60. Which is not to say that they are ignorant about the real world-only that litigants are afforded a chance to treat them as if they were.

61. A widely respected chief circuit judge once told me (with characteristic humor): "I got my job the old-fashioned way: political patronage."

62. Unlike a judge, a physicist can develop and utilize his special knowledge in complete isolation, except, perhaps, from his peers. And I would suggest that while a lawyer's specialized knowledge concerns prediction (how a case will come out) and persnasion (affecting the probability of that result), that of a judge concerns evaluation (how a legal issne should be resolved) and cognitive isolation (preventing irrelevant persuasion from clouding his evaluation). 


\section{A. The Difference Between Professional and Bureaucratic Discipline}

Professionals typically organize associations and disciplinary structures for purposes of self-control..$^{63}$ In the United States, a paradigmatic exaniple is the medical profession. Doctors exercise a state-enforced monopoly over their area of expertise, and typically determine the standards for the right to enter their professional order and for dismissal of wayward members. ${ }^{64}$ This self-discipline generates respect and naintains the value of the professional franchise in the public eye. Because prestige is so important to professional groups ${ }^{65}$ they can be clannishly self-protective when dealing with non-professionals. ${ }^{66}$ For example, doctors and lawyers are often reluctant to publicly criticize the work of their peers. ${ }^{67}$ Internally, however, the value of public prestige motivates the profession to sanction wayward members itself when necessary to preserve public respect. ${ }^{68} \mathrm{Often}$ professional discipline happens informally and covertly, so as to minimize public attention and negative perceptions. But however professionals choose to control their peers, they generally agree that adherence to professional standards or practices should never be evaluated by the public at large. ${ }^{69}$ The value of this insight should already be clear: It suggests that judges would much rather discipline theniselves in matters that they believe are within their specialized knowledge than have laypersons intrude.

Society sometimes recognizes and validates a profession's internal controls. By yielding control to the professional community, society obtains indirect control over professional conduct, an approach typified by the treatment of medieval craft guilds. ${ }^{70}$ Modern society, however, often takes a different tack. Professionals are increasingly subject to evaluation and control by individuals who are not necessarily menibers of the professional group, or are professionals whose allegiance is primarily to the controlling authority. These individuals are managers, whose authority derives

63. See BLAU \& ScotT, supra note 51, at 62-63; Eliot Freidson, Professional Powers 63-88, 166-68 (1986).

64. They typically do this with government sanction. See, e.g., CAL. HealTH \& SAFETY CODE §§ 2000, 2007 (West 1990) (establishing state board of examiners for California-but note that this board does contain lay members, albeit a small minority).

65. See MOORE, supra note 48 , at $110-18$ for a detailed history of professional control, from medieval guilds to modern times.

66. Professionals have a strong and normatively supported tendency to emphasize the collegiality of the occupation-witness the use of the title "brother" for peer judges. See id. at 109.

67. See id. at 111.

68. See BLAU \& SCOTT, supra note 51 , at 63.

69. See FREIDSON, supra note 63, at 141 (1986) ("The minimal characteristic of the professional ... is technical autonomy, the freedom to employ discretion in performing work in the light of personal, presumably schooled, judgment that is not available to those without the same qualifications."); MOORE, supra note 48, at 111.

70. See William J. Goode, Community Within a Community: The Professions, 22 AM. Soc. Rev. 198 (1957). For more on the model of medieval guilds, albeit from an unsurprisingly economic viewpoint, see Richard A. Posner, Overcoming Law 39-46 (1995). 
from the rational principles of bureaucratic administration articulated by Max Weber. ${ }^{71}$

Whereas professionals derive their authority from superior knowledge or esoteric skills, bureaucrats secure their authority from fiat. ${ }^{72}$ This distmction is obvious if one considers the differing reasons for obeying "doctor's orders" and a police officer's command to "pull over." We listen to doctors because we trust their acquired techmical expertise. In contrast, we obey police officers because of an implicit legal contract backed by formal sanctions. Because bureaucratic control is typically exercised by non-professionals, it operates quite differently from professional control. Generally, bureaucratic control takes the form of impersonal rules and regulations, advance planning, and the use of performance records for objective evaluation. ${ }^{73}$ In contrast, professionals see their work as governed by a set of standards determined by their colleagues and peers. ${ }^{74}$

\section{B. Judicial Independence as Professional Independence}

In sociological theory, then, I fmd signposts pointing to a final facet of judicial independence: professional imdependence. This independence consists of a sociologically predictable preference of the judicial profession to engage im self-control and to resist external, bureaucratic processes that evaluate and supervise the professional behavior of its members. Sociologists argue that professional and bureaucratic principles naturally oppose each other, and that conflict is inevitable when the two coexist. ${ }^{75}$ Professionals resist managerial authority because their own authority derives not from fiat but from specialized knowledge, training, and competence. ${ }^{76}$ They generally hate to be supervised by a bureaucracy. ${ }^{77}$ When they are, they resist its rules, reject its standards, evade its supervision, and

71. See Max Weber, From Max Weber: Essays in Sociology 196-244 (H. H. Gerth \& C. Wright Mills trans., 1946). Weber asserted that bureaucratic coordination, characterized by careful attention to rationality, was the hallmark of the modern era. He argued that bureaucracies are superior to other forms of organization, despite their problematic characteristics. See LEWIS A. CoSER, MASTERS of Sociological Thought 230-33 (1971); GidDENS, supra note 53, at 287-89.

72. See Scott, supra note 52 , at 273.

73. See WeBER, supra note 71, at 196-98.

74. See Montagna, supra note 49, at 176-81; Howard M. Vollmer \& Donald L. Mills, Introduction to W. Richard Scott, Professionals in Bureaucracies-Areas of Conflict, in Professionalization 265, 265 (Howard M. Vollmer \& Donald L. Mills eds., 1966).

75. See BLAU \& ScorT, supra note 51; see also GIDDENS, supra note 53, at 297 ("As organizations come increasingly to rely on [professionals], hierarchichal systems of the bureaucratic type are liable to come under strain."); MonTAGNA, supra note 49, at 178 ("Most empirical studies .. . have shown how bureaucracy is antithetical to professional norms and goals."); Scott, supra note 52, at 268 ("[C]onflicts and problems result whenever [bureaucracy and professional approaches] are merged into a single structure.").

76. See Scott, supra note 52, at 273.

77. See id. Contrast this with judges' nearly unquestioning obesiance to their internal professional hierarchy, consisting of the system of appeal, reversal, and inandamus. See Fremson, supra note 63 , at $163-64$. 
condition their loyalty to it. ${ }^{78}$ Professionals are only able to function within bureaucracies to a point:

When ... the professional feels that adherence to bureaucratic norms will lead to a violation of the norms of his professional group, he is likely to rebel. In doing so, he may incur the wrath of his bureaucratic superiors but will at the same time gain support from his professional colleagues both within and outside the organization. ${ }^{79}$

One can hardly imagine a better theoretical explanation of the events discussed in my introduction.

The sociological perspective on professional behavior informs several portions of iny discussion. First, where judicial discipline inechanisıns are used to ensure democratic public accountability, a judge is unlikely to rebel as a professional; it is not his professional judgment that is being questioned but rather his political judgment. In contrast, where the legal merit of a judicial decision is criticized—or worse, sanctioned-by those outside the judicial community, we can expect negative reactions within the judiciary because of the perceived trespass upon an exclusive professional territory. However, these reactions are more likely to manifest themselves in simple refusal to submit to the imposition of outside legal authority. ${ }^{80}$

Accordingly, the area in which the professional independence of the judiciary becoines most important is where bureaucratic forces are deployed to control the processes by which judges go about their profession. When the public attenipts to regulate a judge's courtroom demeanor, his treatment of attorneys, or his senility, it confronts this least discussed form of judicial independence: the judiciary's professional independence. Attempts to impose public norms of behavior and conduct upon any profession meet resistance froin its inembers, and the judiciary is no exception. ${ }^{81}$ If we use bureaucratic means to intrude upon areas in which judges hold professional values more dear than their allegiance to bureaucratic norms, then we will both alienate thein and inmpair their effectiveness-just as placing bureaucratic limits upon the conduct of a doctor may severely

78. See Scott, supra note 52, at 273. See also Stephen R. Barnett, The Bureaucourt, CAL. LAw., Sept. 1996, at 27. While Professor Barnett suggests that the California Supreme Court operates as a bureaucratic institution, I don't believe our positions are incompatible. Since the high court's judges stand at the apex of its bureaucracy, they feel no conflict. Were that bureaucracy to be controlled by non-judges (for example, by some outside authority issuing decision deadlines), the Justices might resist vigorously.

79. Scott, supra note 52, at 270-71.

80. If for no other reason than the fact that objections couched in the latter form can be justified by structural necessities. See supra Part I.B.

81. See A Career Under Fire: Howard Broadman Spent Years Fighting Discipline Charges, The Recorder, Jan. 5, 2000, at 1 (quoting Judge Broadman as saying "I think the Commission on Judicial Performance is a clear and present danger to the independence of the judiciary, that they are a bureaucraey out of control ...."). 
impair her effectiveness. ${ }^{82}$ Perhaps more than other professionals, judges must simultaneously abide by internal professional norms and public norms, and this "dual membership" severely limits our ability to control them "m a rational manner with respect to [our] own goals."

III

\section{Examining Traditional Methods of Judicial Discapline}

In Parts I and II of this Comment, I have suggested a set of competing values at stake in judicial discipline. In light of those suggestions, I now discuss the benefits, drawbacks, and implications of the most common inethods of judicial control: ${ }^{84}$ impeachment, electoral controls (including both recall and end-of-term elections), and the institutions of inandamus and appeal. In addition, I examine the characteristics of informal disciplinary processes and the role of civil and criminal sanction as disciplinary inechanisms. While I hope this investigation is not entirely without independent value, it serves primarily to illustrate the valuable place that JCOs can occupy in the public's disciplinary toolbox.

\section{A. Achieving Democratic Accountability: Impeachment and Election}

\section{Impeachment}

In the federal judicial systein, impeachment is the only method available to reinove a judge from office. ${ }^{85}$ Impeachment is available in all of the

82. See id. (quoting Judge Broadman as saying "I think I lost my independence as a judge" and noting his self-censorship after being investigated by the CJP); see also Rust v. Sullivan, 500 U.S. 173, 218 (1991) (Blackmun, J., dissenting) (" $[R]$ egulations tending to confine the attending physician in an undesired and uncomfortable straitjacket in the practice of his profession, cannot endure.") (internal quotation marks and citations omitted).

83. Scott, supra note 52 , at 266.

84. Marvin Comisky and Philip Patterson list nine "principal" methods of judicial discipline in their book on the judiciary:

(i) removal by the executive branch ("executive action"); (ii) legislative removal by impeachment ("impeachment"); (iii) legislative removal by joint resolution of botl louses ("joint resolution"); (iv) removal by the governor on address by both louses of the legislature ("address"); (v) removal during a judge's term of office by recall election ("recall"); (vi) removal by defeat in regular elections at the end of a judge's term of office ("nonreelection"); (vii) removal or discipline by a court in proceedings initiated in the courts ("court discipline"); (viii) removal or discipliue by disbarring or disciplining judges in their capacities as members of the bar ("bar discipline"); and (ix) removal or discipline in a proceeding before a permanent disciplinary commission or special disciplinary tribunal ("commission discipline").

Marvin Comisky \& Philip C. Patterson, The Judiciary-Selection, Compensation, Ethics, AND DISCIPLINE 149 (1987) (citing Edward J. Sclıoenbaum, A Historical Look at Judicial Discipline, 54 CHI.-KENT L. REV. 1, 1-22, 24-25 (1977)). Of these, "executive action" has essentially disappeared throughout the country, "joint resolution," "address," and "bar discipline" are rarely used, and the JCO process lias largely supplanted "court discipline." See CoMISKY \& PATTERSON, supra, at 149-52 (citations omitted).

85. See U.S. Consr. art III, § 1 ("The Judges, both of the supreme and inferior Courts, slall hold their Offices during good Behaviour ...."); U.S. CoNsr. art II, § 4 ("The President, Vice President and 
states as well, although it is not always an exclusive mechanism. ${ }^{86}$ Such proceedings are the ultimate weapon in any dispute over judicial misconduct: in these conflicts, the countermajoritarian judge meets his majoritarian makers, and if a sufficient number of votes against him are cast, he loses his position, no matter what his offense.

Because of this plenary power, impeachment (along with elections, discussed infra) is one of the few disciplinary mechanisms capable of preserving democratic public accountability. Alexander Hamilton noted the political character of impeachment even at the birth of the federal Constitution, ${ }^{87}$ stating that impeachment trials would tend to divide the community "into parties more or less friendly or inimical to the accused." 88 This political character has two consequences of imterest for judicial discipline. First, actual rules and standards for what conduct constitutes an inpeachable offense are few and far between-and may well be irrelevant where they do exist. ${ }^{89}$ The political will cannot easily be cabined into predetermined standards; just as citizens cannot be told what information is relevant in a general election, legislators cannot be told what to consider during an impeachment trial. ${ }^{90}$ In the context of political passions, rules are largely unimportant.

This absence of standards results im the second consequence of interest with respect to judicial discipline. If we wish to protect a judge's countermajoritarian independence against the onimipotent impeachment process, the necessary restraints must be political, rather than legal. And indeed they are. Nearly all impeachment provisions demand supermajority votes, often isolatimg a judge from narrowly partisan removal. ${ }^{91}$ In addition, impeachment trials are time consuiming and expensive. Legislators must put aside all other business to bring charges and conduct a trial against a judge, a risky choice when the judge's behavior escapes the attention of the press and voters.

These political safeguards inevitably limit the utility of impeachment mechanisms for purposes other than creating democratic public

all civil Officers of the United States, shall be removed from Office on Impeachment for, and Conviction of, Treason, Bribery, or other high Crimes and Misdemeanors.").

86. See Schoenbaum, supra note 84 , at $1-25$.

87. The Federalist N o. 65, at 331 (Alexandcr Hamilton) (Garry Wills cd., 1982) ("IImpeachments are] of a nature which may with peculiar propriety be denominated PoLITICAL, as they relate chiefly to mjuries done immediately to the society itself.").

88. Id.; see also LaUrence H. Tribe, American Constitutional Law § 2-7, at 154 (3d ed. 2000) (describing the impeachment law as "by its nature highly political").

89. See VolCANSEK, Judicial Misconducr, supra note 45.

90. See The Federalist No. 65, supra note 87, at 332 (arguing that impeachments "can nevcr be tied down by such strict rules ... a as in common cases serve to limit the discrction of courts.") This is not to say that standards are useless. While they cannot protect a judge whose decisions or conduct are fatally out of sync with public expectation, they can raise the threshold for his removal.

91. See, e.g., CAL. CoNST. art. IV, $\S 18$ (requiring a two thirds majority of the state Scnate to remove a judge from office through impeachment). 
accountability. Because the political threshold for initiating proceedings is so high, it is nearly inpossible to use them to enforce adherence to legal norms, much less to sanction a judge for noncriminal misbehavior or poor judicial demeanor. As a practical matter, legislators can only initiate these procedures in cases of flagrant misconduct, and can only sanction the inost egregious behavior. ${ }^{92}$ The federal judiciary's impeachment record is instructive: in over 200 years of constitutional history, only thirteen federal judges have been impeached by the House of Representatives, and, of those, only seven were convicted by the Senate. ${ }^{93}$

Another drawback of impeachment as a inechanisin for serving anything but democratic public accountability is its inability to guide future conduct. Because impeachment is used so rarely, and because each impeachment case tends to have umique features and historical context, there are few solid precedents to guide the impeachment process. ${ }^{94}$ When combined with its lack of standards, ${ }^{95}$ we can see that it fails to provide a guide to judges of what is and is not acceptable conduct. ${ }^{96}$ Thus, impeachment leaves inuch to be desired as a stand-alone disciplinary mechanisin. ${ }^{97}$

92. See Testitor \& Sinks, supra note 26, at 1 .

93. See Volcansek, Judiclal Misconduct, supra note 45, at 89. (1) The first was Federalist Judge John Pickering of New Hampshire, discussed supra at note 45. (2) Next, in 1862, the Senate convicted District Judge West $H$. Humphreys of supporting secession and holding judicial office in the Confederacy (during which he tried Umion loyalists for their crime of support). (3) Commerce Court Judge Robert W. Archibald was reınoved from office in 1912 for abuse of judicial influence to further his busimess interests and for soliciting personal contributions from lawyers in his court. (4) The wellknown story of Halsted Ritter comes next. A District Judge in Florida, Ritter allegedly showed favoritism, evaded income taxes, handled bankruptcy litigation irregularly, and illegally accepted money from his former law partner. His conviction, however, came for bringing his court "into scandal and disrepute, to the prejudice of said court, and public confidence in the administration of justice therein." Fifty years passed until the next group of impeachment convictions, all based upon criminal investigations by the Justice Department. (5) District Judge Harry Claiborne attempted to continue in office even after conviction for tax evasion and making false statements, but his plan was thwarted by the Senate in 1986. (6) District Judge Alcee Hastings was acquitted of bribery and corruption in his criminal trial, but was convicted by the Senate after investigation by a committee of federal judges pursuant to the Judicial Conduct and Disability Act. (7) Finally, District Judge Walter L. Nixon was convicted on November 3, 1989 of accepting an illegal gratuity and of committing perjury before a grand jury. See VolCANSEK, Judicial Misconduct, supra note 45, at 90-99. Of course, this record may misrepresent the true number of "effective" impeachments because judges, like other officials, tend to resign when faced with the imminent prospect of impeachment. Since 1818, a total of 22 judges have done so. See id. at 89.

94. See VolCANSEK, JUDICIAL IMPEACHMENT, supra note 29 , at 7.

95. See VolCANSEK, Judictal Misconduct, supra note 45 , at 99.

96. Note, however, that in the aftermath of the failed impeachment trial of Supreme Court Justice Samuel Chase (for inter alia, active participation in an election campaign) federal judges were said to "improve remarkably" and thereafter refrained from participation in partisan politics. See id. at 91-93 (citing Richard B. Lillich, The Chase Impeachment, 4 AM. J. LEGAL Hist. 46-60 (1960)).

97. See TESTITOR \& Sinks, supra note 26, at 1 . 


\section{Electoral Controls}

A paradox of the judicial "profession" is that so many judges are selected, not by their peers, but by the public at large in popular elections. At present, elections are the primary method for selecting state judges-some thirty-nine of the fifty states utilize them in some form..$^{98}$ Judicial elections have their roots at least in part in disciplinary concerns, particularly in the difficulty of removing unfit judges by other means. ${ }^{99}$ Before the turn of the twentieth century, this concern, along with a belief that the alternatives (generally executive appointment) were worse, led most states to select and retain judges through electoral processes.

Because a purely electoral process is essentially an unguided affair, it is well-suited to effecting democratic accountability. Proponents of the electoral system typically note that "judges make policy, and therefore, should be directly chosen by, and accountable to, the people who will be subject to or affected by those policies." 100 This very trait, however, subjects the electoral process to heavy criticism from commentators. ${ }^{101}$ The most common concern is that judicial impartiality demands freedom from political obligations; elections corrupt the very nature of the judging task. ${ }^{102}$ Moreover, there exists a general sense that the qualities desirable in a judge may not necessarily be related to the qualities required to win a popular election-captured im the aphorism that "[t]he worst of judges may run the best of campaigns and be reelected." 103 In efforts to free the judicial system as a whole from political influence, many states attempt to isolate courts from overtly political pressure by utilizing nonpartisan elections ${ }^{104}$ or systems in which judges are appointed but can later be removed by popular vote. Of course, the federal system goes even further by eliminating elections entirely.

Aside from their unavoidable threats to judicial decisionmaking, elections have another key limitation: in practice, they cannot vindicate values other than democratic public accountability. Voters do not have enough

98. See Steven P. Croley, The Majoritarian Difficulty: Elective Judiciaries and the Rule of Law, 62 U. Chi. L. Rev. 689, 725 (1996). California's electoral process for judges is mandated by Artiele VI, $\S 16$ of its constitution.

99. See VolCANSEK, Judicial Misconduct, supra note 45 , at 105.

100. ComisKy \& PATterson, supra note 84, at 8 (citing, inter alia, Ray M. Harding, The Case for Partisan Election of Judges, 55 A.B.A. J. 1162 (1969)).

101. See, e.g., VolCANSEK, JUdicial Misconduct, supra note 45, at 106.

102. See Croley, supra note 98.

103. TESTITOR \& Sinks, supra note 26 , at 1.

104. See VolCANSEK, Judicial Misconduct, supra note 45 , at 105 . The value of having nonpartisan elections is not entirely clear. Donald Jackson and James Riddlesperger suggest that in the absence of other information, political affiliation can convey some information to aid a voter's decision. See Donald W. Jaekson \& James W. Riddlesperger, Jr., Money and Politics in Judicial Elections: The 1988 Election of the Chief Justice of the Texas Supreme Court, 74 JudiCATURE 184, 189 (1991). 
information to make reasoned decisions about a judge's fitness for office, and thus elections cannot meaningfully ensure adherence to legal norms and proper judicial behavior. ${ }^{105}$ Incumbent judges are very rarely voted out of office and in many cases are not opposed at all. ${ }^{106}$ When they are removed, it normally has little to do with disciplinary concerns: voters are more apt to hold them accountable for unpopular decisions than for ethical infractions or undesirable courtroom behavior. ${ }^{107}$ Some commentators even argue that voters fail to differentiate between judges, and votes for or against judges tend to reflect swings in overall trust in government more than an individual judge's fitness. ${ }^{103}$ This leads many to believe that electoral devices have rarely resulted in the removal of unfit judges. ${ }^{109}$

\section{B. Enforcing Legal Norms: Appeal and Mandamus as Discipline}

Appellate reversal and mandamus may not immediately spring to mind as disciplinary mechanisms, but they are critically important means for enforcing the second of the three disciplinary values enumerated in Part I. As previously noted, the judiciary's freedom from political interference rests in part upon its willingness and ability to enforce the rule of law within its ranks. Mandamus and appeal are the judiciary's primary tools to address these types of legal error.

Both mandamus and appeal have important limitations. One is that they do not reach the judge himself, but only his decisions. Generally, appeal and mandamus orders do not carry personal attributions of error or assignation of fault; appellate courts try to depersonify the lower court judge and simply state that "the court below" made a mistake. ${ }^{110}$ As one judge states, these mechanisms correct "honest error" that, unless intentional or belligerent, does not call for punishment so much as correction, or

105. See Burbank, supra note 32 , at 316 (suggesting that the public's knowledge base about the judiciary is "abysmal"); Marie Hojnacki \& Lawrence Baum, Choosing Judicial Candidates: How Voters Explain Their Decisions, 75 JUDICATURE 300 (1992) (suggesting that voting in even contentious elections tends to follow patterns typical of low-information contests). But see Nicholas P. Lovricli et al., Citizen Knowledge and Voting in Judicial Elections, 73 JuDICATURE 28 (1989) (arguing that those voters who do vote in judicial elections tend to be well informed).

106. See Lawrence Baum, American Courts: Process and Policy 102 (1990).

107. See TEsTitoR \& Sinks, supra note 26, at 1.

108. See VolCANSEK, Judicial Misconduct, supra note 45, at 106 (citing William K. Hall \& Larry T. Aspin, What Twenty Years of Judicial Retention Elections Have Told Us, 70 Judicature 340 (1987)).

109. See, e.g., Schoenbaum, supra note 84.

110. See Charles Gardner Geyl, Informal Methods of Judicial Discipline, 142 U. PA. L. REv. 243, 287 (1993) (stating that "[1n]andamus and reversal are designed to correct error, not to call the judge to task for misbehavior."); id. at 288, 308 ("[T]he appellate court that grants relief often characterizes the misbehavior in question as a mistake to be corrected, rather than as misconduct to be avoided, inaking its action nondisciplinary in tone and effect."). But see id. at 287 (stating that "circuit court opinions can ... encourage the judge who does her job well and... chasten the judge who does not"). 
"setting straight." ${ }^{111}$ This may simply be the judicial profession's natural response to the fact that both processes are highly public and visible. ${ }^{12}$ In order for the profession to maintain its respect in the eyes of the public, it must not attribute errors to the faults of its members, and thus corrections must not carry stigma or "sting." Otherwise, they might become unwieldy and ineffective tools for dealing with routine legal error.

Another key limitation upon these mechanisms is their rigid standards for application. Because mandaunus and appeal must be obeyed unquestioningly by the judiciary, it is important to limit their application to situations of real error and not mere quibbles over judgment. Standards for appellate reversal in applying law to fact normally involve tremendous deference to the fact-finding ability of lower court judges. Generally, de novo review is reserved for only the most abstract legal issues. Standards for mandainus orders tend to be similarly exacting. ${ }^{113}$

These two limitations, so critical to maintaining the effectiveness of appeal and mandamus as tools for policing adherence to legal norms, severely limit their ability to vimdicate the other disciplinary values I have identified. Because direct orders do not target the errant judge himself, they may fail to change his future behavior. ${ }^{114}$ And because aggrieved parties must fit their complaints within narrow prerequisites im order to obtain relief, mandainus and appeal cannot deal with the vast array of misbehavior that threatens public expectations of professional judicial conduct rather than legal conclusions. These problems led Judge Harry Edwards of the United States Court of Appeals for the D.C. Circuit to state that "it has never been assumed that mandainus or reversal are useful tools to deal with the ongoing problems of judicial misconduct."115 In this context, I might sharpen Edwards's declaration to say that these mechanisms cannot be used to serve disciplinary values other than adherence to legal norms.

\section{Civil and Criminal Sanctions}

Neither civil nor criminal sanctions merit much attention in a discussion of judicial disciplinary methods. As for civil sanction, it is generally assumed that judges, like other government officials, should possess some degree of immunity from civil liability for their official acts. ${ }^{116}$ On the other hand, a variety of tribunals have held that judicial title does not render its

111. See Harry T. Edwards, Regulating Judicial Misconduct and Divining Good Behavior for Federal Judges, 87 Mich. L. REv. 765, 794 (1989).

112. See Sahl, supra note 30, at $204 \mathrm{n} .43$ ("Writs of mandamus and appellate review are essentially public methods of regulating judicial conduct.").

113. See Geyll, supra note 110, at 288-89.

114. See id. at 294.

115. Edwards, supra note 111, at 794; see also Burbank, supra note 32, at 346 ("[J]udicial misbehavior is more difficult to remedy through the judicial process than judicial disobedience.").

116. See ShAMAN ET AL., supra note $27, \S 14.01$, at 489. 
holder immune from criminal responsibility, even for acts committed in the course of office. ${ }^{117}$ But punishing criminal activity by judges does not directly vindicate any of the three values I articulated earlier. As long as a judge retains office, criminal sanction does little other than illustrate that even a judge is not above the law.

In the federal sphere, at least one Article III judge has retained his commission and attempted to continue in office even after a felony conviction. ${ }^{118}$ Article III countenances no shortcuts-impeachment was the only way to remove him from office. ${ }^{119}$ Of course, the threat of criminal sanction "has induced a number of corrupt [federal] judges to resign." ${ }^{20}$ In some states, on the other hand, statute, rule, or constitutional enactment automatically removes a judge from office upon conviction of certain crimes. ${ }^{121}$ Though the standards differ, these provisions share in common the aim of removing judges from office who are convicted of serious crimes. ${ }^{122}$ Not surprisingly, criminal conduct also typically violates the Code of Judicial Conduct. ${ }^{123}$

Criminal behavior is nonetheless an infertile ground for discussions of judicial discipline. A judge who merits criminal sanction for official behavior (by accepting bribes, for instance) will, in all likelihood, be quickly sanctioned by one of the other disciplinary mechanisms discussed herein. When a judge commits a crime in his unofficial capacity, the situation raises more interesting questions. The critical one appears to be what sort of crimes a judge could commit in his personal life that would intrinsically make him unfit to serve. This and other questions, however, are beyond the scope of my Comment.

117. See, generally, Bratelien v. United States, 17 F. 2d 888 (8th Cir. 1945); McFarland v. State, 109 N.W.2d 397 (Neb. 1961). The leading treatise on this subject notes that a narrow exception applies where states criminalize malfeasance or misfeasance in office. In such states, judicial immunity does protect the judge who engages in such action without bad faith. See SHAMAN ET AL., supra note 27, \$ 14.11, at 509. The life tenure provision of Article III was not meant to shelter criminal behavior, and therefore criminal sanction for federal judges need not be preceded by impeachment. See Uinted States v. Isaacs, 493 F.2d 1124 (7th Cir. 1974).

118. Judge Harry Eugeue Claiborne, U.S. District Judge for the District of Nevada, stubbornly retained judicial title and stipend after his 1984 conviction for making false statements on tax returns. See generally VOLCANSEK, JUDICIAL IMPEACHMENT, supra note 29, at 36-43.

119. Congress did impeacl and convict Claiborne in 1986. See id. at 60-64.

120. National Commission on Judicial Discipline \& Removal, Report of the National Commission on Judicial Discipline \& Removal 2 (1993) [hereinafter Commission Report].

121. See SHAMAN ET AL., supra note $27, \S 14.12$, at 511 .

122. See id.

123. See, e.g., Model Code OF Judicial Conduct Canon 2A (1990) ("A judge shall respect and comply with the law...."). 


\section{Informal Discipline: Policing Professional Norms}

The remaining controls I wish to discuss are informal controls. The term "informal" sweeps broadly, ${ }^{124}$ but I use it here to refer to the aggregate of professional coercion mechanisms, ranging from the subtle, such as friendly counseling by a fellow or chief judge, to the drastic, such as prompting adverse publicity within the bar or even among the general public. These methods have probably existed as long as the judging profession itself, ${ }^{125}$ but are extremely difficult to study. Often the very reason that they are so effective is that they operate as an alternative to more public disciplinary mechanisms. ${ }^{126}$ But despite the relative lack of data on the use of informal discipline, ${ }^{127}$ some important observations can be made.

First and foremost, informal discipline appears to be extremely efficient and effective in many situations. ${ }^{128}$ Although judges may be prone to exaggerate the virtues of informal procedures over external bureaucratic controls, ${ }^{129}$ it does seem evident that they often respond much better to persuasion than to being "bossed around." 130 In the federal judiciary, at least, "informal actions by the chief circuit and district judges appear to be used with the most frequency and to the greatest effect," ${ }^{, 131}$ so much so that one survey concludes that they are "nearly always" successful, ${ }^{132}$ and that when they $d o$ fail, more formal orders are unlikely to work either. ${ }^{133}$

The root reason for this high success rate is the collegiality and professional nature of the informal peer process. Sociological literature predicts that informal and collegial policing methods will be highly effective

124. See Geyh, supra note 110, at 281-82 (listing various methods of informal control).

125. Indeed, some sociologists suggest that informal procedures tend to evolve wherever formal rules are inflexible. See Giddens, supra note 53, at 289-90 (citing Peter M. BlaU, The DYNAMics of BUREAUCRACY (1963)).

126. See Geyh, supra note 110 , at $246-47$ (noting that his investigation of informal discipline was difficult because much of it happens "'off the record,' making it difficult to assess the frequeney and effectiveness with which such methods are used.").

127. One notable exception being Charles Gardner Geyh's study of disciplinary mechanisms, which was based on a survey of federal chief judges. See id.

128. See Irving R. Kaufman, Chilling Judicial Independence, 88 YALE L.J. 681, 709 (1979) ("Peer pressure is a potent tool. It should not be underestimated because it is neither exposed to public view nor enshrined in law."); see also Edwards, supra note 111, at 794.

129. A result that is hardly surprising, if the analysis presented in Part II, supra, is accurate. Peter Fish quotes one chief judge as saying that more could be accomplished "by a diplomatic handling of a bad situation where cooperation of the district judges is necessary than by coercion under authority of law." Peter G. Fish, The Politics of Federal Judicial Administration 162 (1973).

130. See id. at 413.

131. Geyh, supra note 110 , at 276 .

132. Id. at 282.

133. See id. at 268 ("Formal orders are nnlikely to succeed where informal methods of persuasion fail."). The efficacy of informal discipline suggests the main reason for protecting professional independence. Since the desire to monitor and discipline one's colleagues is charaeteristic of a professional group, to the extent that we care to preserve the beneficial features of informal discipline, we must take care to preserve professional independence. 
agencies of control within a professional group. ${ }^{134}$ Thus, it should come as no surprise that judges usually see informal discipline-especially when imposed by their superiors-as a "teaching" rather than a "disciplinary" process. ${ }^{135}$ Judges understandably react more favorably to criticism "couched as a friendly suggestion" than to hierarchically mandated directives. ${ }^{136}$

Informal professional discipline is also capable of reaching misconduct that does not merit formal sanction at all. ${ }^{137}$ Formal procedures such as appeal and mandamus must operate within relatively rigid ex ante guidelimes because their authority stems from the rules themselves. In contrast, a judge's peers can address concerns, such as a subjectively poor temperament, that are difficult to enshrine in bureaucratic guidelines without riskmg discretionary enforcement. This may explain reports that informal discipline is particularly effective in cases of judicial disability ${ }^{138}$

But informal discipline has serious limitations. First, and most instrumentally, collegial approaches do not always work, especially with a stubborn or obdurate judge. ${ }^{139}$ In addition, a judge who has substantial disabilities may be impossible to reach through these methods. These problems mean that informal discipline cannot always vindicate the critical value of adherence to legal norms; those norms demand not only more certain means of enforcement, but also means that are more accessible to litigants. Second, informal professional controls are entirely incapable of providing democratic public accountability for the judiciary. Since their efficacy depends upon shared professional norms, the lay public cannot use them to impose its will upon the judiciary.

This brimgs up a limitation that strikes at the very heart of what informal controls do address-adherence to professional standards of competence and conduct. Collegial controls are by definition imposed upon a judge by a fellow member of the judicial profession. If a court stenographer were to critique a judge's courtroom demeanor, the judge would, in all likelihood, reject the advice, despite the fact that it comes from a source whose view on the issue is as valid as that of any judge. Thus, to the extent that the judiciary's mternal professional norms fail to reflect those of the public, informal processes cannot yield results that the public seeks. In a profession so clearly engaged in public service, occupational behavior

134. See MoORE, supra note 48, at 119 ("Without review aud enforcement mechanisms, professional codes may be little more than wimdow dressing .... Yet it is also important to stress the efficacy of informal controls.").

135. See Jeffrey N. Barr \& Thomas E. Willging, Decentralized Self-Regulation, Accountability, and Judicial Independence Under the Federal Judicial Conduct and Disability Act of 1980, 142 U. PA.

L. REv. 25, 137-38 (1993).

136. Geyh, supra note 110 , at 283 .

137. See id. at 306.

138. See id. at $271-76$.

139. See TESTITOR \& SinKs, supra note 26 , at 1 . 
standards cannot be dominated by the professional group itself, because those norms (which I will call "guild norms") may not reflect the desires of the public. If this does lappen, the discord between public expectation and professional standards will lead the public to "the perception ... that judges cannot be trusted to judge themselves." ${ }^{140}$

\section{IV}

\section{The Place of JCOs: Lessons From the Federal Judicial CONFERENCES AND THE CJP}

In the preceding Part, I suggested that existing methods of judicial control typically vindicate one of the three disciplinary values articulated earlier, and have important limitations that curtail their effectiveness in such a way as to preserve various facets of judicial independence. I come now to what are simultaneously the most troublesome and most promising means of judicial discipline: judicial conduct organizations (JCOs). $\ln$ this Part, I describe two JCOs, the Califorma CJP and the federal judicial councils, in soine detail. I examine both organizations, and show their critical difference: whereas the federal JCOs are essentially professional organizations that compleinent collegial disciplinary measures and enforce professional conduct norms, California's CJP has both a more bureaucratic character and a inore plenary grant of power. As a result, while the federal systein is attacked for an mability to import public expectations of professional conduct into the judicial profession, criticisms of the CJP come largely froin judges, who chafe at its intrusions upon their professional and legal independence.

\section{A. The Federal Judicial Conference: Plenary Power Controlled by the Profession}

Although the federal Judicial Conference was created in 1922, Congress first gave it serious and specific disciplinary powers and responsibilities with the 1980 Judicial Councils Reform and Judicial Conduct and Disability Act. ${ }^{141}$ The Act was desigued to "allow judges to monitor the conduct and competence of disabled and imisbehaving peers, without resort to the cuinbersome machmery of impeachment." ${ }^{142}$ In was, in short, an attempt to create an alternative and nore nuanced approach to discipline in the federal judiciary. Although many observers have questioned the constitutionality of disciplinary procedures beyond the impeachment clause of

140. Geyh, supra note 110 , at 309.

141. Pub. L. No. 96-458, 94 Stat. 2035 (1980) (codified at 28 U.S.C. $\S \S 331,332,372,604$ (1994). Many judges resisted the development of formal penal procedures on essentially professional grounds, saying that "[y]ou don't have to threaten judges to get them to carry out the directions of the councils." FISH, supra note 129, at 161-62 (quoting Chief Judge John Parker).

142. VolCANSEK, JUdiclal MisCONDUCT, supra note 45 , at 101. 
the Constitution, ${ }^{143}$ I will not confront that issue here, given the judicial approval of the Act. ${ }^{144}$

\section{Broad Powers Cabined by Professional Composition}

The Judicial Conference of the United States, which consists of all the chief circuit judges and one district judge chosen front each circuit, oversees the operation of the entire federal judiciary. ${ }^{145}$ The twelve judicial councils, neanwhile, are enupowered to "nıake all necessary and appropriate orders for the effective and expeditious administration of justice" within their respective circuits. ${ }^{146}$ Under the Act, any person can file a coinplaint against a judge "who has engaged in conduct prejudicial to the effective and expeditious administration of the business of the courts, or ... is unable to discharge all the duties of office by reason of physical or mental disability." ${ }^{147}$ Although several circuits read the first phrase to mean that coinplaints should be dismissed if they do not allege "significantly" troubling behavior, ${ }^{148}$ this grant of power reaches a broad range of professional conduct unrelated to a judge's adherence to legal norms.

The federal judicial councils' grant of authority is quite sweeping. However, few judges or citizens have complained that the councils' use of this power has encroached upon countermajoritarian, legal, or professional independence. This is because the councils have limited their efforts to avoid conflict with existing means of discipline, and have viewed the formal coinplaint mechainsm as a ineans for reinforcing collegial controls rather than as a inandate for imposmg bureaucratic controls. This restraint is due primarily to their composition: Congress's charter was for a "selfregulation" organization, under a model devised by the judiciary itself..$^{149}$

In the federal systein, complaints are filed with the chief judge of the circuit court, who reviews the complaint, and sends a copy to the judge whose conduct is at issue. At her discretion, the chief judge nay dismiss the complaint for a variety of reasons. ${ }^{150}$ If she decides not to dismiss, she inust appoint a committee to investigate the complaint and report to the

143. See, e.g., Edwards, supra note 111, at 765.

144. See In re Imperial “400" Nat'l, Inc., 481 F.2d 41 (3d Cir. 1973), cert. denied, 414 U.S. 880

(1973).

145. See 28 U.S.C. \$ 331 (1994).

146. Id. \$332(d)(1).

147. Id. § 372(c)(1).

148. See Geyh, supra note 110 , at 251,253 ("[M]isconduct complained of may have to reach a certain magnitude before it will be deemed prejudicial to judicial administration.").

149. See COMMISSION REPORT, supra note 120 , at 4.

150. These reasons include: (1) the charges are frivolous, (2) the charges fall outside the jurisdiction of the Act, (3) the complaint concerns a judge's decision on the merits of a case, or (4) corrective action has cured the problem. See 28 U.S.C. \$ 372(c)(3). See generally Victor Williams, Third Branch Independence and Integrity Threatened by Political Branch Irresponsibility: Reviewing the Report of the National Commission on Judicial Discipline and Removal, 5 SETON HaLl CONST. L.J. 851, 893 (1995). 
circuit judicial council. ${ }^{151}$ The written report recommends a resolution: dismiss the complaint, certify disability, urge voluntary retirement, freeze the judge's caseload, or privately or publicly censure the judge. ${ }^{152}$ If the committee feels that the judge should be removed, it can refer the case to the Judicial Conference, which can in turn certify to the House of Representatives that impeachment may be justified. ${ }^{153}$

At every level of inquiry, proceedings under the Act are conducted entirely by judges, who are keenly aware of the difference between professional and bureaucratic discipline. ${ }^{154}$ Moreover, unlike the citizen members of the California CJP, the judges' disciplinary role is at best a secondary responsibility; their loyalty is primarily to their bulging dockets. When combined with the fact that these judges can unilaterally dismiss complaints at various stages without further review, and the limited public access to inforniation on case disposition, ${ }^{155}$ it is hardly surprising that $\mathrm{t}^{1} \mathrm{e}$ councils engage in little official action. ${ }^{156}$

In light of the structure of the federal judicial conncils, it seems strange that the Report of the National Commission on Judicial Discipline and Removal would claim that Congress was "principally concerned with assuring public accountability in the 1980 Act."157 In this context, "public accountability" must mean something different from the concept I discussed earlier. ${ }^{158}$ A self-regulatory organization cannot vindicate the goal of democratic public accountability; only the public or its politically elected representatives can do that. Neither can "public accountability" be taken to mean that the councils were meant to enforce adherence to legal nornis. As proof, consider the broad ability of chief circuit judges to dismiss complaints that concern the merits of a legal decision. ${ }^{159}$ If exercised-and evidence indicates that it is ${ }^{160}$-this authority would preclude

151. See 28 U.S.C. $\$ 372(c)(4)$.

152. See id. \& 372(c)(6).

153. See id. \& 372(c)(7).

154. See, for example, a 1959 resolution by the Ninth Circuit judicial council, resolving that the council would not take "any action which might be construed by the district judges as an effort to crack the whip over them, so as to ensure that the judge did not think herself just another employee taking orders from a judicial council acting as a quasi board of directors." FisH, supra note 129, at 406-07 (emphasis added).

155. See infra Part IV.A.3.

156. From 1980 to $1991,2,405$ complaints were filed with the councils, the majority of which alleged unethical behavior on the bench. Of these, only forty resulted in the formation of a special committee, and only thirteen survived summary dismissal by the circuit judicial councils. In total, the complaints resulted in seven reprimands, three voluntary retirements, one termination of a magistrate judge, and one impeachment. See COMMISsION REPORT, supra note 120, at 87-99.

157. Id. at 4.

158. See supra Part I.A.

159. See 28 U.S.C. § 372(c)(3) (1994).

160. See supra note 156; see also Geyh, supra note 110, at 271 ("[T] $]$ he judicial councils' general authority to issue necessary and appropriate orders is rarely exercised as a means to regulate judicial misconduct and inaction.”). 
any atteinpt to use the councils to vindicate this disciplinary goal. But why not allow the councils to do so? After all, the councils are not so different from the panels that typically decide appeals; they might be eminently qualified to examine a record for legal error. On reflection, however, it seems dangerous to discipline a judge for committing legal error in a case without correcting the ruling in the case itself. Until the councils have that power, they cannot enforce adherence to legal norms in any meaningful way. ${ }^{161}$

Thus, Congress's concern for "public accountability" in the 1980 Act is ultimately a hope that the councils will police adherence to professional standards of conduct and behavior. Given their exclusively professional composition, it should be no surprise that the councils have done so only in a limited sense. ${ }^{162}$ As described in Part $I I$, any professional group can be expected to engage in disciplinary action in such a way as to preserve its respect in the eyes of the public. Judges are no exception to this, and as a result, they are reluctant to impose formal public sanction upon a colleague. ${ }^{163}$ Like other professional groups, they will seek to informally and collegially correct behavior as an alternative means of discipline.

\section{Reinforcement of Informal Discipline}

Reliance on such alternative disciplinary mechanisms is not necessarily unfounded; earlier in this Comment, I suggested that informal methods of judicial discipline may in fact be the most effective. Of course, part of their appeal and power lies in their role as an alternative to formal judicial discipline. The two methods, however, do interact, and whether this interaction is beneficial or detrimental appears to be a function of the structure of the formal disciplinary process.

In the federal sphere, many observers claim that the provision of formal disciplinary mechanisms under the 1980 Act vastly increased the efficacy of informal discipline. Prior to the Act, chief judges' suggestions could easily be ignored. Even the prodigious William Taft felt powerless: "The fate of a Chief Justice im attempting to make District and Circuit Judges do what they are not disposed to do is a difficult one," he said, going on to note that the fact that his suggestions often went unheeded was "a

161. Other problems come to mind as well. For example, should the parties be allowed to argue in such proceedings?

162. Although the National Commission on Judicial Removal and Discipline's investigation reported that the vast majority of complaints dismissed by the judicial councils were frivolous, it noted that some complaints alleging "bias on the basis of race, gender, or sexual orientation" were dismissed summarily, without even preliminary investigation, and that such concerns may be a "serious problem" within the federal courts. CoMmission REPORT, supra note 120, at 99.

163. One chief circuit judge stated explicitly that "we think nothing would furnish potential critics of the circuit council with ammunition more than would overaction." In re Imperial " 400 " Nat'l, Inc., 481 F.2d 41, 47 (3d Cir. 1973). 
pretty good indication that I have no function to perform in the matter of disciplining judges." 164

After the 1980 Act, however, chief judges have often been able to use the threat of formal sanction in which they are participants as a powerful coercive force, adding teeth to the collegial discipline process. ${ }^{165}$ Chief judges apparently use complaints to identify problematic behavior and then encourage accused judges to "shape up" before the chiefs are forced to initiate formal proceedings. ${ }^{166}$ This threat adds valuable heft to the chief judge's suggestions, ${ }^{167}$ and that incentive is maximized when the chief judge himself is a part of the formal disciplinary proceedings. ${ }^{168}$ Thus, the interaction between informal and formal discipline in the federal judiciary is facilitated by the procedures of the judicial councils. Where judges are afforded a measure of control over the imitial stages of deciding whether to discipline a judge, they are able to use the formal process to reinforce informal discipline. This structure has a secondary benefit: conduct that might not merit formal sanction can still be addressed because a superior judge is still informed of the problems in his subordinates.

\section{Criticism of the Federal JCOs}

Unfortunately for the individual complainant in the federal system, the visible result of an informal solution to a formal complaint (dismissal) is less than satisfying. Were there complete disclosure about the proceedings, these concerns might be alleviated to some degree. However, this is not the case. The Act provides that all allegations and investigations conducted under its authority be confidential unless they result in public reprimand or referral to the House of Representatives. 28 U.S.C. $\S 372$ (c)(14) states that "all papers, documents, and records of proceedings related to mvestigations conducted under this subsection shall be confidential and shall not be disclosed by any person in any proceeding . ..."169 Chief judges have generally construed this provision as establishing a more "general rule of confidentiality" for proceedings under the Act, ${ }^{170}$ with soine exceptions. ${ }^{171}$

164. F1SH, supra note 129 , at $88-89$.

165. See Geyh, supra note 110 , at 283 ("[T] remedying judicial misconduct provides an incentive for judges to take seriously the informal suggestions of the chief circuit judge.").

166. See id. at 283-84.

167. See id. at 283; see also Fish, supra note 129, at 162.

168. See Geyh, supra note 110 , at 283.

169. 28 U.S.C. $\$ 372$ (c)(14).

170. Sahl, supra note 30 , at 218 .

171. First, a judicial council has discretion to release its report to the complainant or to the judge or magistrate whose conduct is the subject of the complaint. See 28 U.S.C. § 372(c)(14)(A) (1994). Second, the Act specifically allows the council to release information "believed necessary to an impeachment investigation or trial of a judge under Article I of the Constitution." Id. $\$ 372(\mathrm{c})(14)$ (B). 
This confidentiality has led some commentators to complain that the Act provides only "secret discipline."172 Such complaints point to a primary drawback of the federal JCOs. While their secrecy allows the effective use of informal disciplinary approaches, it also prevents complainants and the public from examining what norms of professional behavior, competence, and conduct are being enforced by the collegial process. In the absence of scrutiny, those standards are likely to be professional or guild norms, ${ }^{173}$ and nay be quite removed from public desires. In a democracy, this is a problematic result, and as suggested earlier, it may impair the public's perception of the fairness of judicial proceedings and hence the legitimacy of the judicial system itself.

Overall, the 1980 Judicial Councils Reform and Judicial Conduct and Disability Act gives the federal judicial councils relatively broad authority over disciplinary matters. However, they have largely declined to exercise the full reach of this authority and have avoided disciplining judges to achieve political accountability or to enforce adherence to the rule of law. As I have articulated, this reluctance is a result of the councils' composition. In the saine way that political limits on impeachment and rule-based limits on appeal and mandamus prevent those mechanisms froin interfermg with other facets of judicial independence, the composition of the judicial councils limits their interference with countermajoritarian, legal, and professional independence. But this composition also tends to imsulate the profession from public norms of professional conduct, an undesirable result in a deinocracy.

\section{B. The California CJP: Plenary Power Without Concomitant Control}

Like the federal judicial councils, state JCOs were a direct response to the widespread perception that the disciplinary mechamisms described earlier in this article were inadequate to police growing judiciaries. Although other states made earlier attempts, ${ }^{174}$ California took the first major step in

Third, the judge being investigated can request disclosure to the public. See id. Finally, the Conference can vote to recommend that the House of Representatives consider impeachment or other "appropriate" action. Id. $\$ \S 372(c)(6)-(c)(9)$ On a practical level, the Act's procedures are extremely confidential; when the chief judge of a circuit dismisses a complaint, the written order excludes the name of the judge and the complainant. See id. $\$ 372$ (c)(8)(A); Salıl, supra note 30, at 220. Complainants themselves are, however, generally free to inake their complaints public even after engaging in formal proceedings. See Special CoMatte of the Conference of ChIEF Judges of THE U.S. Courts of Appeals, Illustrative Rules Governing Complaints of Judic1al Misconduct and Disability WITH COMMENTARY Rule 1(b) (1986); Sahl, supra note 30, at 222-23 (noting that under this Rule, "the judiciary still retains virtually complete discretion concerning what and how much information to provide in support of orders dismissing a complaint or concluding proceedings").

172. Sahl, supra note 30 , at 222-58.

173. Such norms are created by a guild for the purpose of furthering its own needs, rather than improving the product it provides to the public. See POSNER, supra note 70, at 43.

174. In the 1940 s and 1950 s, some states developed investigation procedures through their state bar associations, and Michigan established disciplinary procedures through its supreme court. In 1948, 
the creation of state judicial conduct organizations when it created the Commission on Judicial Performance (CJP) ${ }^{175}$ by constitutional amendment in 1960 . Since then, every other state has followed suit. ${ }^{176}$ California was also the first state to view the mclusion of laypersons as a crucial eleinent in JCO credibility. ${ }^{177}$

The CJP remains an appropriate model for study. Not only is it the oldest, largest, and most influential state $\mathrm{JCO},{ }^{178}$ but it also represents an extreine in coinposition and authority. The majority of its members are not judges, nor even lawyers, and its authority is quite broad. Although the rules governing its procedures were formerly inade by the California Judicial Council, consisting entirely of judges, it now has authority over its own rules. ${ }^{179}$ In this Part, I suggest that the CJP lacks safeguards to prevent it from attempting to vindicate democratic public accountability or adherence to the rule of law, two functions for which it is structurally unsuited. In addition, while the CJP's coinposition enables it to import public norms of professional conduct, it simultaneously increases judicial resistance to its orders and advice when it tries to do so.

\section{Broad Statutory Authority Without Compositional Limitations}

As described earlier, the composition of the federal JCOs both channels their broad authority toward the goal that they are competent to serve-enforcing professional standards of conduct and competence-and prevents encroachments on the relevant facet of judicial independencewhich I have called professional independence. Although the CJP has similarly broad authority, it lacks correspondingly necessary structural limitations. Thus, while it can seek to vindicate all three goals of judicial discipline, it also threatens all three versions of judicial independence: countermajoritarian, legal, and professional.

New York established a Court on the Judiciary, a special six-judge tribunal that convened only to hear cases of judicial misconduct or disability. But this panel had the shortcomings of the legislative proceedings described earher. It lacked a confidential mechanism to screen and investigate misconduct allegations, and its only power was outright removal. See TESTITOR \& SINKS, supra note 26, at 2.

175. The CJP's original name was the Commission on Judicial Qualifications, but that name was changed by amendment in 1976. CAL. ConsT. art. VI, § 8. (West Annotated Code, 1996).

176. See TESTITOR \& Sinks, supra note 26, at 2.

177. See id. at 5 .

178. The CJP oversees an immense number of judges: California has 1,580 authorized judgeships. See California Courts: Questions and Answers (visited Feb. 2, 2000) <http://www.courtinfo.ca.gov/q\&a/qa7.htm>. This exceeds the size of the federal judiciary and makes California's system the largest among western nations. See Comments by California Supreme Court Justice Kathryn M. Werdegar at Boalt Hall's Seminar on Judging, February 2, 2000 (on file with author). While it is thus unsurprising that the CJP is the largest JCO in the nation in terms of its budget and staff, it is far larger than its competitors in this regard.

179. See CAL. CONST. art. VI, § 18(i); see also Recorder v. Commission on Judicial Performance, 85 Cal. Rptr. 2d 56, 60 (Cal. Ct. App. 1999) (discussed infra). 
Little precludes the CJP from attempting to impose democratic public accountability upon the California judiciary. ${ }^{180}$ Under Article VI of the California constitution, the CJP may act on any of the following allegations: ${ }^{181}$

- "willful misconduct in office;",182

- "persistent failure or inability to perform the duties of office;"

- "habitual intemperance in the use of intoxicants or drugs;"

- "conduct prejudicial to the administration of justice that brings the judicial office into disrepute;", 183

- "a disability that seriously interferes with the performance of the duties of office and is or is likely to become pernnanent;"

- "improper action or a dereliction of duty."

Taken together, these standards seem to give the CJP broad authority to discipline judges. Certainly, the power to discipline "conduct prejudicial to the administration of justice that brings the judicial office into disrepute" appears on its face to allow discipline for decisions such as refusal to administer the death penalty. ${ }^{184}$ This expansive grant of authority could allow the imposition of political will upon the judiciary, as impeachment or election mechanisms can do. Further, the CJP's mandate seems to include the power to inpose disciplinary sanction upon judges who commit legal

180. But see note 211 , infra.

181. The language of these standards comes from CAL. CoNST. art VI, $\$ 18$.

182. The California Supreme Court has interpreted "willful misconduct" to have two elements: the misconduct must be done with malice or in bad faith, and must be committed while the judge is acting in a judicial capacity. See Adams v. Commission on Judicial Performance, 897 P.2d 544,547 (Cal. 1995). "Bad faith," in turn, means that a judge "must have (1) committed acts he or she knew or should have known to be beyond his or her power, (2) for a purpose other than faithful discharge of judicial duties." Id. However, the phrase "should have known" does not mean that mere neghigence can satisfy the bad faith element. See Broadman v. Commission on Judicial Performance, 959 P.2d 715, 720-21 (Cal. 1998).

183. This allegation "may be committed by a judge either while acting in a judicial capacity, or im other than a judicial capacity." Adams, 897 P.2d at 547. If conduct "would appear to be prejudical to public esteem for the judicial office" to an objective observer, even in the absence of bad faith, it would run afoul of this provision. See id. at 547; Kloepfer v. Commission on Judicial Performance, 782 P.2d 239, 241 (Cal. 1989); Geiler v. Commission on Judicial Qualifications, 515 P.2d 1, 9 (Cal. 1973).

184. This provision has been interpreted rather expansively by the Califoruia courts. A judge's intent or motivation is "not a significant factor in assessing whether prejudicial conduct has occurred under this standard." Adams, 897 P.2d at 547 (citing Gonzalez v. Commission on Judicial Performance, 657 P.2d 372 (Cal. 1983)). Moreover, "[a]lthough a judge may perform the necessary judicial functions diligently, competently, and impartially, his or her mability to [avoid] activities that reasonably would be perceived as damaging to the judiciary may place that judge's fitness for judicial office in doubt." Adams, 897 P.2d at 547. Any failure to comply with the California Code of Judicial Conduct, for example, suggests prejudicial conduct. See id. 
error, ${ }^{185}$ even though they lack the power to reverse a decision on the merits of a case.

One way to limit the practical reach of such authority would be to vest it in the professional group, which, im light of Part I's insights, is unlikely to fully exercise it. But while the eleven members of the CJP include three judges, they also include two lawyers and six citizens who are not judges, retired judges, or members of the State Bar. ${ }^{186}$ With eight of the CJP's eleven members appointed by political bodies for relatively short terms, ${ }^{187}$ one could speculate that they might attempt to impose the views of a dominant political party upon the judiciary through complaint procedures. Indeed, this very accusation has been leveled at the organization in the past, not only in Kline's case, but upon past appointments of politically opinionated members. ${ }^{188}$ Enforcing democratic public accountability is one important component of judicial discipline. The problem with having the CJP address it, however, is that a group of eleven relatively anonymous appointees seems manifestly unsuited to the task of representing the popular will. As for enforcing legal norms, the CJP's structure allows legal review to be instituted by a majority group that is not legally trained, an undesirable result. If the legal independence of California's judiciary is to be maintained, the CJP must carefully avoid this role, and yet little in its charter seems to prevent it from taking it on.

\section{Lack of Procedural Limitations}

Another way to limit the practical reach of disciplimary authority is to impose difficult procedural hurdles that will raise the threshold for action. Here, again, the CJP seems to lack structural linits. It can instigate action relatively easily, upon a written complaint or sua sponte, upon any other information it receives. ${ }^{189}$ In response, it can either dismiss the complaint as

185. Either because it could be construed as failure to perform the duties of office or as conduct prejudicial to the administration of justice. See CaL. CoNST. art. VI, \& 18(d)(1)-(2).

186. See id. $\$ \S 8(\mathrm{a}), 8(\mathrm{~b})$. The CJP's present composition was set only recently, in 1994, by the passage of Proposition 190. See Recorder v. Commission on Judicial Performance, 85 Cal. Rptr. 2d 56, 71 (Cal. Ct. App. 1999). Proposition 190 stated that its chief purpose was "to eliminate judicial domination of the commission in favor of a public majority." Id. (internal citations omitted). Prior to 1994, the CJP had only nine members: five judges, two lawyers, and two citizens. See CAL. CoNST. art VI, \& 8 (West Annotated Code 1994).

187. The judges are appointed by the California Supreme Court, the lawyers by the Governor (they must be "members of the State Bar of California who have praeticed law in this State for 10 years"), and two citizens each by the Senate Committee on Rules, the Governor, and the Speaker of the Assembly. See CAL. CoNST. art. VI., § 8(a). Each member is appointed to a four-year term. See id.

188. See Harriet Chiang, Judges Fear Panel Partisanship, S.F. Chron, May 24, 1995, at A1. Such charges were made when then-Governor Pete Wilson appointed victims' rights advocate Harriet Solarno to the CJP. Solarno was quoted as saying that sle hoped to teach judges "how to be more sensitive to victims," and suggested that there miglit have been a role for formal disciplinary mechanisms in removing Chief Justice Rose Bird. Solarno's remarks fueled judges' concerns that her pohtical agenda made her unfit to serve. Id.

189. See Comm. ON Judicial Perf. R. 109(a). 
"unfounded or frivolous,"190 or "make a staff mquiry to determine" if the facts "warrant a preliminary investigation." "191 If the staff inquiry determines "sufficient facts," the CJP can conduct a "preliminary mvestigation to determine whether formal proceedings should be instituted." ${ }^{192}$ The preliminary investigation involves procedures similar to those of the staff inquiry: the judge is notified, the proceedings are terminated "if the preliminary investigation does not disclose sufficient cause to warrant further proceedings", and the CJP can issue the judge a confidential advisory letter. ${ }^{193}$

Based on the preliminary investigation, the CJP can choose to issue a public or private admonishment. ${ }^{194}$ But if the preliminary investigation reveals facts that warrant formal proceedings, or if an accused judge demands them, the CJP's procedures continue. After notifying the offending judge and the public, ${ }^{195}$ the commission schedules a hearing, before either the CJP or a panel of special masters that report to the commission. ${ }^{196}$ At the completion of the hearings, the nrasters submit a final report to the CJP, with findings of facts and law. ${ }^{197}$ The examiner and the accused judge then file briefs with the CJP, ${ }^{198}$ and may argue their cases before it. ${ }^{199}$ Based on this, the CJP nay either dismiss the proceedings or issue sanctions, ${ }^{200}$ which can include "admonishment, censure, removal, or retirement." ${ }^{201}$ All sanction decisions can be reviewed by the California Supreine Court. ${ }^{202}$

Other disciplinary mechanisms with broad authority, such as impeachment and electoral processes, are so difficult to undertake that they are unlikely to be used to enforce legal norms, and the remedies they provide are so blunt as to make them fatally unwieldy even if they were more

190. Id. R. 109(a)(1).

191. Id. R. 109(a)(2).

192. Id. R. 109(a)(3). If a staff inquiry does not find that a matter warrants action, the commission must terminate the inquiry. See id. R.110(b). At that time, it may issue the judge a confidential advisory letter after giving the judge an opportunity to respond to the inquiry and the nature of the charge. See id. R. 110.

193. Id, R. 111.

194. See id. R. 113-116. Before issuing the admonishment, the CJP must give the offending judge notice of its intent. See id. R. 113, 115. At that time, the accused judge can choose to accept the admonishment, file written objections and "demand an appearance before the commission," or demand a formal hearing. Id. R. 114, 116. After the judge has his chance to be heard, the CJP can issue the admonishment, downgrade the sanction to an advisory letter, or terminate the proceedings without any disciplinary action. See id. R. 114(b), 116(b).

195. See id. R. 118, 119.

196. See id. R. 121. Upon the consent of the accused judge, a single master can be substituted. See id. R. 121(b). The special masters are judges appointed by the California Supreme Court upon the CJP's request. See id. R. 121(b).

197. See id. R. 129.

198. See id.R. 130.

199. See id. R. 132.

200. See id. R. 134.

201. Id.

202. See CAL. Const. art. VI, \& 18(d). 
readily accessible. In contrast, the CJP seems able to issue semipublic "stinger" letters fairly easily, and these letters appear capable of directing the legal decisions of a judge. ${ }^{203}$ Although higher-order sanctions such as removal are preceded by inore rigorous procedural requirements, the CJP's composition inay dilute their miportance. Unlike other disciplinary bodies, inany of the CJP's meinbers are not structurally required to make discipline a secondary interest. For example, while the federal judicial councils' meunbers are necessarily loyal primarily to their own dockets, CJP members may have the time and energy to navigate its full range of procedures, especially given their significant staff resources. Overall, the CJP's procedures may not impose hurdles - at least beyond those imposed on all other disciplinary actions-significant enough to protect the countermajoritarian or legal independence of the judiciary. ${ }^{204}$

\section{Sidestepping Informal Controls Fails to Utilize Their Strengths}

As described earlier, the initial stages of a complaint in the federal JCOs are handled by judges, whereas in the CJP, they are handled by a group largely inade up of private citizens. This difference inerits careful consideration. If, as most authorities agree, many complaints against judges are frivolous or unfounded, any system that places initial review responsibilities in the hands of a lay commission loses a significant chance to exert informal pressure upon judicial conduct. In the California system, a coniplaint that indicates undesirable conduct but does not inerit serious sanction will probably result in a confidential advisory letter from the commission. ${ }^{205}$ Such a letter may even be the first a judge has heard of the complaint against him. ${ }^{206}$

Coming, as it does, from outside the professional group, this type of letter lacks the authority of coercion by the judge's peers and will probably be ignored. It may well encroach on judicial independence without any corresponding beneficial change in judicial behavior. In a similar situation in the federal judiciary, the probable outcome would be an informal

203. See generally Oberholzer v. Commission on Judicial Performance, 975 P.2d 663 (Cal. 1999) (reviewing sanctions imposed upon Judge Richard J. Oberholzer for his dismissal of a criminal proceeding in which the prosecution appeared unprepared to try the case).

204. Compared to the record of the federal judicial councils, see supra note 156, the CJP has been quite active. From 1990 to 1999, the CJP considered 10,322 complaints, and instituted investigations in over 1,183 of those. Based on those investigations, the CJP issued 377 advisory letters, 105 admonishments, and eleven censures. In addition, it ordered six removals, and 41 judges chose to resign while being investigated. See 1999 Cal. Comm'n on Judicial Performance AnN. REP. 91.

205. See supra Part IV.B.2.

206. At the staff inquiry stage of the complaint procedures, the CJP is not obligated to inform the investigated judge of the proceedings, unless 1) the judge makes a written request that "specifically describes the underlying incident giving rise to the complaint," 2) "the pendency of the complaint has become generally known to the public," or 3) "the judge has received written notice of the complaint from" a source other than the CJP. COMM. ON JuDICIAL PERF. R. 109(d)(1)-(3). 
communication by the chief judge, an approach that may well bear more fruitful results. Thus, it appears that while the federal judicial councils both "back up" informal controls and provide valuable information to a judge's superiors in order to encourage proper behavior, the CJP operates independently from the informal process, to the potential detriment of both forms of discipline. In Part V, I suggest a possible solution to this problem.

\section{The CJP's Advantages and Disadvantages}

The CJP's defenders would probably meet my concerns with the response that the group was never meant to carry out political desires or enforce legal norms. Instead, it was meant to correct ongoing problems of competence and unprofessional behavior within the court system. ${ }^{207}$ For this task, they would argue, and I would agree, the CJP seems wisely constituted. In fact, the constitutional amendment that set the CJP's present structure was a direct response to the perception that its prior composition-five judges, two lawyers, and two laypersons ${ }^{208}$ - had become "demonstrably clubby, secretive and ineffective im dealing with judges who misbehaved or had become incompetent." ${ }^{209}$ This is sociologically unsurprising. If it fails to allocate significant authority to members from outside the profession, any organization that imtends to police professional standards of conduct will inevitably impose only guild discipline, ${ }^{210}$ the group will sanction only the most outrageous conduct and will attempt to resolve the majority of problems in a secretive and collegial fashion. In a democracy, the judiciary must not develop and admimister a conduct code in isolation and im secret. It must instead be held to public as well as professional conduct norms. Thus, the use of significant numbers of laypersons and a relatively streamlined set of procedures which often result simply im public letters of disapproval seems an appropriate approach. ${ }^{211}$

207. See, e.g., Adams v. Commission on Judicial Performance, 897 P.2d 544, 569 (Cal. 1995) (stating that the purpose of a CIP proceeding "is not punishment, but rather the protection of the public, the enforcement of rigorous standards of judicial conduct, and the maintenance of public confidence in the integrity and independence of the judicial system"). Broad statements sucll as these seem only to reinforce my point.

208. See Cal. Const. art VI, $\$ 8$ (West Annotated Code 1994).

209. A Less-Than-Stellar Start, L.A. Times, Aug. 15, 1995, at B-8.

210. See Posner, supra note 70, at 39-46.

211. It is possible to argue that the CIP's powers are inherently limited because a disciplined judge can appeal his punislıment to the California Supreme Court, whicll must sustain the charges of misconduct if there is clear and convincing evidence sufficient to prove them to a reasonable certainty. See CAL. ConsT. art. VI, § 18(g); Kennick v. Commission on Judicial Performance, 787 P.2d 591, 597 (Cal. 1990). Howevcr, I believe that this protection is Iess robust than it might appear. First, the publicity associated with such a defense is likely to strongly deter judges from contmuing this far. Second, the cost of such a defense is often borne by the judge himself. For example, the bill for Justice Kline's defense, which did not proceed beyond the initial stages of investigation, totalled $\$ 29,985$. See Rinat Fried, Kline's Bill for Appeal Seems Like A Good Deal, THE RECORDER, Oct. 12, 1999, at 4 (suggesting that this fee was quite low, considering the counsel Kline retained). This sum would have been no small burden, despite the fact that the bill appeared to be heavily discounted. See id; Rinat 
Moreover, the CJP's proceedings appear fairly open to public review. While its rules declare that all papers and proceedings before the commission shall be confidential, ${ }^{212}$ once it institutes formal proceedings, all subsequent papers, findings, and conclusions are nonconfidential, as are the formal hearing before the special inasters and the appearance before the Commission. ${ }^{213}$ Even the investigated judge has access to publicity. ${ }^{214}$ As for the complainant, when an investigation or proceeding is complete, no matter the level to which it proceeds, the CJP must inform the complainant of its conclusion. ${ }^{215}$

In light of the analyses in Part $\mathrm{I}$, however, these laudable desires and seemingly beneficial openness must inevitably conflict with a version of the judicial independence norm too often ignored: professional independence. Six members of the CJP are private citizens who lack even basic training in the law, let alone socialization into the norms of judicial behavior. ${ }^{216}$ If the analysis in Part II applies with any force to the judiciary,

Fried, Justice Kline's Legal Tab Paid off by Judges, THE ReCORDER, Nov. 8, 1999, at 2. Eventually, retired Los Angeles Superior Court Judge Lester Olson spearheaded a successful effort to raise the money from 315 other California judges. See id. In addition, the investigation of a judge is itself a forn of discipline, which cannot be reviewed by the Supreme Court. See, e.g., A Career Under Fire: Howard Broadman Spent Years Fighting Discipline Charges, THE RECORDER, Jan. 5, 2000, at 1 (quoting Judge Broadman: "[W] hat the commission doesn't acknowledge openly is that a mere investigation to a sitting constitutional officer is in some way a form of discipline because you're being looked at by those people who can, in fact, discipline you.... if they keep investigating you when you're doing those kinds of things, then you're not going to do those kinds of things any more, even though you're never disciplined.").

In response to some of these concerns, California's Judicial Council recently voted to approve the purchase of professional liability imsurance for all of California's judges. Upon payment of a premium ( $\$ 450$ for trial judges) the insurance will cover the cost of defending a judge before the CJP, up to $\$ 1$ million per claim. See Judicial Liability Update: Are You Covered?, THE BENCH, Winter 2000 , at 5,12 . However, the judge does not have the right to control his own defense, see id. at 12, and the insurance does not cover criminal charges or charges of sexual harassment.

212. One exception to the CJP's confidentiality rules is that it is obligated, upon written request of any state governor, the United States President, or the California Commission on Judicial Appointments, to turn over admonishments or advisory letters written to judges being considered for a judicial appointment. See Comm. on Judicial PeRF. R. 102.

213. See id. R. 102(b)(1)-(b)(2).

214. If she believes that public reports concerning her proceeding result in "substantial unfairness," she may ask the CIP to issue a statenent of clarification and correction. Id. R. 102(d).

215. See id. R. 102(e). The complainaut's identity remains confidential througbout the CJP's investigation, even during formal proceedings. See id. R. 122.

216. As an example, consider the qualifications of Julie Sommars, a recent citizen appointee to the CIP. See Jean Guccione, Two Superior Court Judges to Join CJP, S.F. DAILY J., March 4, 1999, at 1. Any concerns the reader might harbor about the relevance of Ms. Sommars' experience--she lists herself as a "retired actress"-should be allayed by the relevance of her credits; between 1990 and 1992, she appeared in three "Matlock" episodes, and one "Perry Mason" film. See $<$ <ttp://footprint.moviefinder.com> (visited Mar. 9, 1999). Although the panel does include five legally trained members, three of whom are judges, it seems probable that self-selection among the citizen members encourages at least a countervailing effect. While judges and attorneys derive some professional prestige from the position, the tangible rewards may be limited for citizen members. See Interview with J. Anthony Kline, Presiding Justice, in San Francisco, Cal. (April 7, 2000). One could spcculate that a citizen without prior formal experience in the law would only be interested in a seat on 
we can expect that judges will consistently chafe at any imposition of public norms of professional conduct upon their behavior in office. Justice Kline's aggressive self-defense provides an object lesson in this regard. While Kline was willing, indeed eager, to see his legal argument reviewed by the California Supreme Court, he was vehemently opposed to the imposition of bureaucratic authority upon what he saw as a professional decision to inake that argument. ${ }^{217}$ The argument that the public might well expect its judges to refrain from openly criticizing their superiors and the hierarchical rules of the law, and that the CJP should therefore enforce such expectations as a "conduct" norm, further highlights the conflict in this area. Any attempt to inject a public sensibility into judicial behavior requires the application of the opimion of nonprofessionals, which judges may not share or respect. ${ }^{218}$

\section{$\mathrm{V}$ \\ Disciplining The CALIFornia Commission ON JudicIal PERformance: SOME Proposals}

My arguinents in this Comment do not suggest that the proper approach to reforming the CJP is to disband it. Quite to the contrary, there seems to be little doubt that other existing disciplinary mechanisins at both the state and federal level leave much to be desired. Elections are imprecise and unproductive, ${ }^{219}$ impeachment is unavailable for all but the most severe misconduct, ${ }^{220}$ and both are simply incapable of enforcing all but the most egregious violations of professional conduct and competence. Similarly, while appeal and inandainus are a critical part of the disciplinary puzzle, they are only effective in correcting legal error and fail to deal directly with a problem judge. ${ }^{221}$ Collegial controls, ineanwhile, are well suited to reach professional competence and behavior problems, but the

the CJP if he held a relatively anti-judiciary stance; people who believe their judiciary functions well would probably not seek appointment. Moreover, the politicians who select those citizens may take into account the relatively pro-judiciary stance of the judges on the panel and select citizens with accordingly strong views to the contrary. The controversy surrounding then-Governor Pete Wilson's 1995 appointment of victims' rights advocate Harriet Solarno is an object lesson in this respect. See Chiang, supra note 188.

217. See Interview with J. Anthony Kline, Presiding Justice, in San Francisco, Cal. (April 7, 2000). Moreover, Justice Kline argues, his decision actually accorded with the doctrine of stare decisis, and was thus legally correct. To him, that doctrine is far too coinplex to be policed by a lay commission. See id; see also Amicus Brief of California Judges Association, supra note 15.

218. Consider this statement by a judge in the California Judges Association's quarterly newsletter: "In judicial lore, [the CJP] is something to fear, a bogeyman. This is where careers hang im the balance while a secret tribunal, with public members who could never undersstand, weigh the proof of alleged ethical transgressions." See David Danielsen, CJP's Annual Report Shows Increase in Public Discipline, THE BENCH, Spring 1999, at 5.

219. See supra Part III.A.2.

220. See supra Part III.A.1.

221. See supra Part III.B. 
professional group's interest in maintaining its prestige encourages judges to cover up rather than address problematic behavior. ${ }^{222}$ Further, these controls are often crippled by the fact that judges will often police only guild norms. ${ }^{223}$

In light of these probleuns, it should be apparent that the CJP is perhaps umquely positioned to import public norms of professional competence and behavior into an otherwise insular professional group. ${ }^{224}$ Nevertheless, the analyses presented here suggest that soine reforms are necessary to prevent the CJP from stepping outside the areas that it is coinpetent to police, and to properly protect the countermajoritarian, legal, and professional independence of the California judiciary. None of my proposals are unequivocal or straightforward. Each involves a balance between the affirmative goals of a disciplinary program and the threats that it can pose to various coinponents of judicial independence.

\section{A. Keeping the CJP Within the Bounds of its Competence}

As discussed in Part IV, the CJP currently is empowered to serve disciplinary goals that it is ill-equipped to properly address. Thus, it is necessary to impose structural limits upon the CJP's authority to prevent it from threatening judicial imdependence.

\section{Preventing Adoption of a Political Agenda}

Part IV suggested that little stands in the way of an attempt by the CJP's members to use their offices to impose a political agenda upon the California judiciary. Indeed, this is precisely what many of Kline's supporters alleged as the subtext of the charges against him. The CJP's plenary grant of power allows it to act in situations where misconduct eludes sanction by other mechanisms, ${ }^{225}$ but that same grant also allows it to improperly attempt to ensure democratic public accountability. The CJP is unsuited to the latter task. ${ }^{226}$

This exposes a fundamental tension. Rule-based approaches to limiting the CJP's authority could unduly constrain its actions. It is difficult to cabin in legislative language the exact types of conduct that we wish JCOs to address without excluding some conduct on the margins we would like

222. See supra Part III.D.

223. See id.

224. How else could the requirement that a judge in California be "patient, dignified, and courteous to all litigants, jurors, witnesses, lawyers, and others" be given meaning? CAL. CoDE of Judicial Ethics, Canon 3B(4) (West 2000). Judges might interpret this phrase with a mindset betraying "too much emphasis on the efficient disposition of cases and too little emphasis on the dignity of litigants." Dodds v. Commission on Judicial Performance, 906 P.2d 1260, 1269 (Cal. 1995).

225. See supra text accompanying notes $137-138$.

226. In the worst case, the CJP might atteinpt to impose a political agenda upon the judiciary that does not reflect public desires, but I shall not consider that problent here. 
to see included. At the same time, broad statements of authority allow the CJP to pursue undesirable agendas. One way to avoid the difficult task of drafting more precise jurisdictional rules would be to adjust the composition of the CJP, perhaps so that a majority of its members are appointed by nonpolitical bodies. This might reduce the likelihood that individual members are selected for their political views rather than their overall competence. Finding nonpolitical bodies is quite difficult, however, unless one goes to the judicial branch, which is likely to appoint commissioners with a bias in favor of judicial independence to those seats. Thus, we must also address the tension between the need to effectively enforce public expectations in a disciplinary process and the danger that non-judges inay be willing to impose discipline for improper reasons. Instead of attempting to balance these tensions squarely, I suggest an indirect approach.

First, the CJP needs a careful job description, one that illustrates that its goal should be to police professional conduct but not to investigate the policy preferences of the judiciary. Any attempt to codify this sort of description into law is bound to confront the tension between plenary power and overly restrictive criteria. On the other hand, the current silence on the subject is no better. The California Constitution provides very little guidance for or limits on the CJP's authority, and its broad grant of power is mirrored in the CJP's rules. I would suggest at the very least that the CJP adopt the following statement into its rules:

Members of the Commission on Judicial Performance shall conduct their offices in a scrupulously nonpolitical manner. Members shall not vote to mitiate any disciplinary action upon a judge if motivated even partially by political, partisan, or personal considerations.

This statement by no means attempts to walk the tightrope described in the preceding paragraphs, nor could it be expected to guarantee sigmificant change. It might, however, give a disciplined judge an affirmative defense to use against the commission in the event that she believes she is the victim of a political witch hunt. The mere potential that a judge could issue discovery requests inquirmg into potentially undesirable motivations could deter such motivations from being acted upon.

Second, the CJP should publicize the votes of its menbers on any issue, so that political motivations and factions within the commission can be discovered through careful scrutiny. In this respect, the post-Kline bill that attempted to require disclosure of CJP members' votes in decisions to institute formal proceedings or discipline seemed to hold promise. Although then-Governor Wilson vetoed this provision, known as S.B. $1623,{ }^{227}$ the efforts of Boalt Hall Professor Stephen Barnett and the legal

227. 1997-1998 Sess. (Cal. 1998). Governor Wilson argued that disclosure of votes to institute formal proceedings would actually further politicize the process by committing CJP members to their 
periodical The Recorder secured effectively similar changes through legal action in Recorder v. Commission on Judicial Performance. ${ }^{228}$ In general, the recent "trend toward greater openness and less secrecy" in the CJP's internal procedures is a beneficial development. ${ }^{229}$ Public scrutiny will, at the very least, allow some evaluation of whether CJP voting is divided along party or occupational lines, and can inform any compositional changes that reformers might advocate..$^{230}$

\section{Preventing Policing of Adherence to Legal Norms}

As described earlier, the CJP does not seem to be an appropriate body to enforce adherence to legal norms. ${ }^{231}$ At one level, this problem has been addressed by the California Supreme Court, which declared in Oberholzer v. Commission on Judicial Performance $e^{232}$ that "[m]ere legal error, without more ... is insufficient to support a finding that a judge has violated the Code of Judicial Ethics and thus should be disciplined.' ${ }^{233}$ This begs the question of what "mere legal error" might be. For example, on which side of the line does Justice Kline's behavior in Morrow fall? It seems that Kline's refusal to obey precedent went well beyond an honest legal mistake into active advocacy against the law, and yet the strength of the

decisions. Instead of feeling free to change their votes after hearing evidence, members who voted for proceedings might feel compelled to follow through with disciplinary action. See Order Vetoing S.B. 1623 (Sept. 29, 1998). I find this argument somewhat unpersuasive, if only on the basis of my speculation that the alternative, complete secrecy, is worse.

228. 85 Cal. Rptr. 2d 56 (Cal. Ct. App. 1999). Professor Barnett's co-counsel was Karl Olson, esq., of San Francisco. The Recorder argued that Article VI, Section 18(j) of the California Constitution compelled this result. See id. at 59. Section 18(j) was adopted as part of a 1994 initiative measure known as Proposition 190, and provides that "[w]hen the commission institutes formal proceedings, the notice of charges, the answer, and all subsequent papers and proceedingss shall be open to the public for all formal proceedings instituted after February 28, 1995." CAL. CoNST. art. VI, \& 18(j). The California Court of Appeal agrecd with the Rccorder, stating that in enacting Article VI, voters "must have intended the commission to vote in public or at least to disclose the full rcsults of its vote, mcluding how each commission member voted." Recorder, $85 \mathrm{Cal}$. Rptr. 2d at 59-60. The CJP accepted the decision and now reports its votes, but still does not allow members to publiely dissent from decisions, to Professor Barnett's continuing displeasure. See Interview with Stephen R. Barnett, Professor, University of California, Berkeley, Sehool of Law (Boalt Hall), in Berkeley, Cal. (March 16, 2000).

229. Recorder, 85 Cal. Rptr. $2 \mathrm{~d}$ at 66-67.

230. See id. at 71-72 ("IT]f the public is not allowed to see how the individual appointees are dispensing judicial discipline, it will be unable to determine what, if any, political prcssure might be at work, or the sources of that pressure... Denying public access to full information about the commission's disciplinary decisions deprives the voters of ... [tbeir] ability to make informed decisions regarding the need for positive changes to the system.") (internal quotation marks and citations omitted).

231. See supra Part IV.B.

232. 975 P.2d 663 (Cal. 1999) (reviewing sanetions imposed upon Judge Richard J. Oberholzer for his dismissal of a criminal proceeding when the prosecution appeared unprepared to try the case).

233. Id. at 680. See also Cal. Code of Judicial Ethics, Canon 1 (West 2000) ("A judicial decision or administrative act later determined to be incorrect legally is not itself a violation of the code."). 
opposition to the CJP's disciplinary action indicates that the Commission may not be the appropriate body to address the situation he created. ${ }^{234}$ In addition, there is the question of whether a dissent is a legal action, a chestnut that I cannot hope to crack here.

One path would be to argue that where a judge's error can be remedied by processes internal to the judiciary, such processes should be the exclusive reinedies. Thus, the bounds of CJP authority would be defined by stating that it cannot address legal decisions that can be corrected by appeal or inandamus. I will call this approach "non-duplication." Part II of this Comment suggested that such procedures pose significantly less threat to the professional and legal independence of a judiciary than external bureaucratic control. Another approach would be to argue, as Judge Richard Oberholzer did in his own defense, that a judge's legal ruling should not be able to support a finding of misconduct by the CJP "if the ruling has any intellectual inerit." ${ }^{235}$ However, neither of these approaches seems satisfactory. To the extent that repeated refusal to adhere to precedent violates what the public perceives as basic standards of judicial conduct ${ }^{236}$ and internal judicial mechanisms are unable to persuade a judge to alter his behavior, ${ }^{237}$ bureaucratic discipline inay be the only inechamisin available to satisfy public expectations. Oberholzer recognizes this implicitly in its ruling that "legal error does not preclude a finding of misconduct" by the CJP. ${ }^{238}$ However, such occasions are, in all likelihood, extreinely rare.

This criticisn applies with equal force to the provisions of another post-Kline proposal in California, A.B. $1110,{ }^{239}$ which would have prohibited the CJP from investigating or disciplining a judge solely for a legally incorrect judicial decision or administrative act, or for a reasoned dissenting opinion which did not adhere to precedent set by a higher court. ${ }^{240}$ Then-Governor Pete Wilson vetoed the bill because, among other things, he believed it violated the state constitution and was unnecessary in light of

234. The Oberholzer opinion suggests that Kline's dissent might well have been sanctionable if it had been the opinion for the majority. See Oberholzer, 975 P.2d at 680 ("[A] judge who commits legal error which, in addition, clearly and convincingly reflects ... intentional disregard of the law ... is subject to investigation.").

235. Id. at 679 .

236. For example, the late California Chief Justice Rose Bird's persistent dissenting opinions opposing the death penalty earned her an early retirement at the hands of California's voters, both because of substantive disagreement with her stance (a vindication of democratic public accountability) and because the voters found it inappropriate that a judge should, in effect, legislate from the bench (a violation of public expectations of proper judicial conduct).

237. Appeal and nuandamus cannot be used to sanction a dissenting opinion. Informal discipline nechanisms might have soine effect, but unless the judiciary shares the public's expectations, it is unlikely to be eniployed.

238. Oberholzer, 975 P.2d at 680.

239. 1997-1998 Sess. (Cal. 1998).

240. See Staff of Senate Judiciary Comm. 1997-1998 Sess., Analysis of A.B. 1110 (Aug. 27, 1998). 
the state's Canons of Judicial Ethics. He went on to state that the bill would appear to prevent discipline for even intentional legal error or conduct beyond the judge's authority ${ }^{241}$ - something that Oberholzer did not do. ${ }^{242}$ I will not attempt to evaluate A.B. 1110's constitutionality, but I can offer the following observations.

Assembly Bill 1110's protection of reasoned dissents that refuse to apply precedent presents a difficult question of judicial independence. Judges see the privilege of dissent as essential to their professional independence and any intrusion on that sphere as unwarranted. ${ }^{243}$ To judges, therefore, A.B. 1110 might seem eminently reasonable. But, like the nonduplication approach, A.B. 1110 fails to recognize that repeated dissent can violate public standards for judicial behavior. ${ }^{244}$ The tension between judges' unwillingness to relinquish the important privilege of dissent and the public's desire for a responsive and obedient judiciary poses difficult problems for a rule as simple as A.B. 1110. Nevertheless, the balance here seems to tip in favor of keeping the CJP from disciplining legal opinions expressed im dissent. Reasoned dissents are directed internally to the judiciary and the legal system rather than externally towards litigants. Their effect upon litigants is negligible, and their internal value to judges is high, as indicated by the fact that Kline's cadre of supporters were largely indifferent to the actual issue he raised in Morrow. Thus, where a dissent does not violate public norms other than those associated with judicial fidelity to the law, ${ }^{245}$ it should be insulated from anything other than peer discipline.

The tension between professional independence and public expectations is harder to balance in A.B. 1110's proposal to preclude CJP action solely on the basis of a judicial decision found to be legally incorrect. As discussed earlier, it does seem clear that both the legal and professional independence of the judiciary is threatened when lay commissions sanction judges for legal mistakes. ${ }^{246}$ At the same time, the public has some legitimate expectation that judges will inake an affirmative effort to reach decisions that comport with precedent. The bureaucratic process may well be the only mechanism that can practically police this expectation. As

241. The California Supreme Court has indicated in at least one case that such behavior does constitute "willful misconduct." See McCullough v. Commission on Judicial Performance, 776 P.2d 259, 262 (Cal. 1989).

242. See Oberholzer, 975 P.2d at 680 .

243. See generally Little, supra note 25, (arguing First Amendment and Article III bases for a right to dissent, and noting the presumption among judges that they will be allowed to publicly dissent from court opinions). Professor Little's article introduces a reprint of the late Justice William J. Brennan's essay entitled In Defense of Dissents, 37 Hastings L.J. 427 (1986). In this brief gem, Justice Brennan argues in support of the judicial privilege and obligation of dissent.

244. Again, the public might well expect judges to adhere to precedent and to avoid criticizing the law in public.

245. Such norms include, for example, the expectation that a judge will not express racist biases in legal documents.

246. See supra Parts I.B, II. 
described earlier, internal judicial mechanisms are normally unable to sanction a judge directly, and can only reach the decisions she makes. ${ }^{247}$ At present, California's judges are governed by the decision in Oberholzer, which states
[A] judge who commits legal error which, in addition, clearly and convimcingly reflects bad faith, bias, abuse of authority, disregard for fundamental rights, intentional disregard of the law, or any purpose other than the faithful discharge of judicial duty, is subject to investigation. Mere legal error, without more, however, is insufficient to support a finding that a judge... should be disciplined. ${ }^{248}$

This statement, at the very least, attempts to confront the issue squarely. However, I believe that it fails to provide adequate protection to judges in one way. Under the Oberholzer standard, a judge who refused to apply precedent even for clearly stated reasons would be subject to discipline, even if she accepted and applied the later reversal of a superior court. If one believes that judges commonly refuse to apply precedent and will gladly risk reversal, then the standard might be seen as appropriate. The potential costs to litigants of having a maverick judge on their case are high; they will be forced to pay for expensive appellate litigation in order to enforce the law.

On the other hand, if one believes that judges generally strive to avoid reversal and to adhere to precedent, and depart from it only im the rarest of circumstances, the phrase "intentional disregard of the law" might reasonably be excised froin the earlier standard. Instead, careful application of the CJP's mandate to discipline "conduct prejudicial to the administration of justice"249 combined with a healthy dose of prosecutorial discretion ${ }^{250}$ would better preserve professional independence while giving adequate attention to public norms. The "prejudicial conduct" standard has been interpreted to reflect the reactions of a reasonable objective observer to judicial behavior. ${ }^{251}$ It seems appropriate that this hypothetical human would expect judges to be willing to stand up for their own interpretations of the law on rare occasions, ${ }^{252}$ as long as they are willing to abide by reversal

247. See supra Part III.B.

248. Oberholzer, 975 P.2d at 680 (internal citations omitted).

249. CAL. ConsT., art. VI, § 18(d).

250. See Stephen C. Yeazell, Blown out of All Proportion, L.A. TimEs, Sept. 28, 1998, at B5 (arguing that Kline, the CJP, and the legislature had all "gone off the deep end," and that the CJP's investigation was inerely a prosecutorial indiscretion, which "squander[ed] public funds and [the CJP's] reputation in prosecuting ... an act of uncharacteristically bad judgment").

251. See supra note 183 .

252. See Burbank, supra note 32, at 343-44 ("[]f expressed in isolated dissent, individual disobedience will probably not put a strain on the public's perception of the rule of law."). 
orders handed down by superior courts. ${ }^{253}$ Under this approach, even judges who commit intentional legal error would be free from disciplinary action without evidence of persistent errors on the same legal issue or a convincing pattern of error on multiple issues. Were such evidence present, bureaucratic discipline would be appropriate, as the judge could be assuined to be engaged in routine disregard for the rights of litigants rather than the expression of a limited professional prerogative to instigate debate.

\section{B. Reinvigorating Collegial Controls}

In deciding who should "guard the guardians," we find another fundamental tension. It is true that a judicially-controlled formal discipline process can become a "shotgun behind the door," 254 breathing life into informal discipline. But if it fails to police anything beyond guild norms, the goal of enforcing the public's expectations of judicial behavior may not be served. ${ }^{255}$ The maxim that foxes should not guard henhouses has its roots not only in common sense, but in sociological theory; regulators tied too closely to the institutional systems they supervise exhibit fewer rational characteristics than those enjoying greater independence. ${ }^{256}$

On the other hand, while a citizen-controlled process inay well be unore effective at enforcing public expectations, it can becoine a "shotgun in the dark," wholly divorced froin the peer-influenced gentility of the judicial world. Because "the effectiveness of informal peer pressure ... is based substantially on the prevalence within the judiciary of an atmosphere of good faith and collegiality,"257 a JCO that includes a large fraction of laypersons and imposes sanctions without opportunities for peer intervention may have negative effects upon discipline and independence. Judges confronted by bureaucratic inandates imposed in areas they perceive as inatters of professional judgment are likely to resist ${ }^{258}$ - as Justice Kline did-especially when they are not given an opportunity to appeal to peer

253. As Justice Kline was willing to do. See Morrow v. Hood Communications, Inc., 69 Cal. Rptr. 2d 489, 493 (Cal. Ct. App. 1997).

254. Geyh, supra note 110 , at 283.

255. Organizational theory suggests that for any disciplinary structure to operate in a rational manner it must be relatively isolated from its surrounding institutional environment. See Scott, supra note 52 , at 266 .

256. See S.H. Udy, Jr., Administrative Rationality, Social Setting, and Organizational Development, November AM. J. Soc. 299-308 (1962). Further, some professionals inevitably place loyalty to profession above loyalty to bureaucracy or employer. See BLAU \& ScoTT, supra note 51, at 64.

257. Kaufman, supra note 128, at 711; see also Geyh, supra note 110 , at 305 .

258. This is no surprise, in light of the propositions of Part II, supra. Hicrarchical authority conflicts with professional standards, and "[r]igid discipline stifles professional judgments." BLAU \& ScoTT, supra note 51 , at $185-86$. 
evaluation before formal charges are filed. ${ }^{259}$ Such resistance compromises the overall effectiveness of a disciplinary scheme.

One approach to balancing these concerns would be to integrate collegial controls into the CJP's processes more explicitly-that is, to weld the informal onto the formal. This approach could take several forms in practice. For example, the CJP could be required to consult with an accused judge's superior, for example her chief judge, upon receiving a nonfrivolous complaint. The chief judge could be given thirty days in which to attempt to address the matter collegially. If the chief judge reported back to the CJP that further bureaucratic action was unnecessary, the commission could subsequently choose to dismiss the complaint. However, if the commission had reason to believe that collegial action would be unsuccessful because the chief judge predicted as much, or because the commission believed that the judges were not responding appropriately, it could continue its investigation.

Other permutations of such an approach are easy to imagine, but the overall thrust is appropriate. By giving the judiciary some early ability to intervene in the CJP's process, we may be able to improve simultaneously the efficacy of both collegial controls and bureaucratic controls. Indeed, any examination of the structure or purpose of an organization like the CJP should pause to consider the place of such an institution in the full spectrum of judicial discipline inechanisms. Lay commissions necessarily exist in some tension with informal imternal control mechanisms, a tension that lies in the inherent conflict between bureaucratic authority and professional socialization.

\section{The Problem of Confidentiality}

A final tension in the CJP's operation is that between confidentiality and openness in JCO proceedings. In light of the careful attention that other commentators have given this subject, my imsights here are inodest. ${ }^{260}$ The confidentiality of JCO proceedings has little, if anything, to do with two of the three goals of judicial discipline suggested earlier in this Comment. Deinocratic public accountability and adherence to legal norms can be enforced without significant access to commission proceedings. Since the substance of any judge's decisions is available to the public in the form of tangible results or written opinions, access to commission proceedings and complainits will have little further value with respect to these goals. On the other hand, the goal of enforcing public standards of professional behavior is closely tied to questions of confidentiality. A commission composed exclusively of judges might desire confidentiality in order

259. See generally id. at 245 (suggesting that bureaucrats must make decisions at least in part on administrative considerations, which often conflict with professional considerations).

260. See, e.g., Shaman ET AL., supra note 27, $\$ 13.15$ to 13.19; Sahl, supra note 30. 
to protect the reputation of the profession, but openness could ensure that its members go beyond professional norms to enforce society's expectations of judicial behavior. ${ }^{261}$ An entirely non-professional commission, however, might well be able to enforce public expectations without further scrutiny. Presumably its members would need less supervision to ensure that they would effectuate the public's desires, and hence confidentiality would be less problematic. Thus, confidentiality cannot be considered in isolation. The need for it in a JCO's proceedings rests upon the JCO's composition and the effectiveness of other existing methods of judicial discipline.

Proponents of the practice of keeping complaints against judges confidential ${ }^{262}$ typically suggest that such practices protect "judicial independence." ${ }^{263}$ By considering the various facets of judicial independence separately, we can see more clearly what effects openness might have upon the judicial profession. First, with respect to the countermajoritarian independence of a judge, ${ }^{264}$ it seems hard to imagime that publicizing the proceedings of an organization like the CJP would unearth much beyond what is available from the substance of a judge's orders and opimions. Although the saine might appear to be true of legal independence, ${ }^{265}$ one caveat is that a judge might feel compelled to decide an issue in favor of a party if she thinks that party might level charges at her that would be made public. Fear of initial publicity associated with charges thus could affect the judges decision in a case.

But the facet of judicial independence that seems most directly threatened by openness is professional independence. As I have already discussed, professional groups simultaneously wish to maintain respect in the eyes of the public, and wish to discipline wayward members using internal processes. ${ }^{266}$ As a result, increasingly open proceedings may threaten judges both because they publicly air the judiciary's "dirty laundry" without an effective opportumity to respond ${ }^{267}$ and because they seem to sidestep peer discipline. Peer discipline is more effective in a confidential atmosphere, im part because once a judge's reputation is under public attack, she will see little benefit in responding to informal coercion. There is certainly evidence to suggest that "[m]iscreant judges are more likely to

261. See id. at 248 n.300; Commission REPORT, supra note 120, at 4.

262. All fifty states and the District of Columbia have adoptcd a practice of maintaining confidentiality, at least prior to formal proceedings. See SHAMAN ET AL., supra note 27, § 13.15 at 463.

263. See Sahl, supra note 30, at 225-30.

264. Discussed supra in Part I.A.

265. Discussed supra in Part I.B.

266. See supra Part II.

267. See COMmission REPORT, supra note 120, at 106 (noting that at least one fcderal circuit objected to the requirement of written support for complaint dismissals because of the "tendency of some in the media to highlight, and of the public to remember, that charges were madc, not that they were dismissed."). 
resign or retire voluntarily [where] a veil of secrecy preserves their reputations-for many, their most important professional asset."268 An early commentator on the CJP thus lauded the relative secrecy of its proceedings, claiming that it "protects judges from the effects of publicizing groundless complaints, facilitates the imposition of informal discipline in cases of mimor misconduct, and encourages judges to resign or retire [more efficiently than public trial procedures] in cases of serious imisconduct."269

There is, however, no doubt that fear of publicity is a potent motivating factor for good behavior. One federal chief judge observes that "the threat of newspaper coverage is a big deterrent. Every judge worries about something commg out in the newspaper."270 More importantly, openness allows the public to scrutinize the process of judicial discipline, and assures that the standards imposed mirror those held by citizens. This has led a significant group of scholars to argue that limiting the public's knowledge about judicial performance may prevent the public from being certain that justice is being administered fairly and efficiently. ${ }^{271}$ The risks of a more open process may not outweigh the public's competing interest in having direct access to information about judicial conduct upon the initial filing of a complaint alleging judicial inisconduct. ${ }^{272}$ If balancing seeins intractable, perhaps the realization that the balance is itself influenced by other factors-JCO coinposition and authority, or the presence of other disciplinary mechanisins-suggests that the range of potential solutions is quite broad.

\section{CONCLUSION}

This Comment has suggested that we inipose "discipline" on judges to vindicate three basic goals. The goal of public deinocratic accountability reflects the need for citizens of a democracy to exert some form of control over their leaders and officials, and, broadly speaking, to impose their will upon thein. Adherence to legal norms, meanwhile, reflects a basic characteristic of a functioning judiciary-its adherence to preordained rules of law and political limits upon its powers. Finally, we hope to enforce public norms of professional conduct and competence. Over-aggressive efforts directed towards any of these three goals can threaten judicial independence in its countermajoritarian, legal, or professional forms. Virtually all

268. Sahl, supra note 30, at 232 (emphasis added); see Jeffrey M. Shaman \& Yvette Begue, Silence Isn't Always Golden: Reassessing Confidentiality in the Judicial Disciplinary Process, 58 TEMP. L. Q. 755, 765 (1985) ("[V]oluntary retirement may be an efficient and economical alternative to formal proceedings.").

269. BRAITHWAITE, supra note 44, at 94.

270. Richard L. Marcus, Who Should Discipline Federal Judges, and How?, 149 F.R.D. 375, 428

(1993) (quoting a Federal Judicial Center interview with an anonymous circuit chief judge).

271. See Sahl, supra note 30 , at 248 .

272. See id. at 250. 
mechanisms for judicial discipline target one of these three goals, and have safeguards to ensure that they neither vindicate other goals nor pursue their particular goal too aggressively. At least in California, however, these mechanisms have been considered inadequate, especially with respect to the task of policing the competence and judicial behavior of the state bench.

Like any JCO, the California Commission on Judicial Performance could potentially address many of these concerns, but it has flaws as currently constituted. First, its jurisdiction and authority might encourage it to tackle problems of legal error, or to ensure democratic public accountability-two tasks for which it is manifestly unsuited. Second, its procedures may undercut much of its promise; by mrposing an essentially bureaucratic regime upon the profession and neglecting the virtues of collegial controls, the CJP arouses resistance even as it attempts to accomplish the goal for which it is best suited. I have suggested the general contours of reforms that might address some of these issues, and others may well be necessary ${ }^{273}$ But my suggestions are smiply that; my primary goal has been to identify some of the concerns that thoughtful lawmakers must address in any effort to discipline the professional judge.

273. For instance, lawinakers should consider reform that would address the fact that the CJP integrates investigative, prosecutorial, and recommendatory functions within one body. This has bcen thought to violate due process and the principle of separation of powers. See COMISKY \& PATTERSON, supra note 84; see also Adams v. Commission on Judicial Perfornance, 897 P.2d 544, 550 (Cal. 1995). 